\title{
Nieznane dzieło Pacina di Bonaguidy ze zbiorów prywatnych - przyczynek do badań nad malarstwem florenckiego Trecenta
}

\author{
JAGODA MARCINIAK \\ Dział Inwentaryzatora Zabytków Muzealnych, Muzeum w Koszalinie \\ e-mail: do.jagody.marciniak@gmail.com \\ ORCID: 0000-0003-2168-11787
}

Keywords: medieval art, panel painting, Italian painting, Trecento, Florence, Pacino di Bonaguida, art expertise, Saint Proculus

Słowa kluczowe: sztuka średniowieczna, malarstwo tablicowe, malarstwo włoskie, Trecento, Florencja, Pacino di Bonaguida, analiza zabytkoznawcza, św. Prokulus

\begin{abstract}
The Unknown Work of Pacino di Buonaguida Found in Private Collection Input to the Research on the Paintings of the Florentine Trecento

The paper is aimed at presenting the results of an art expertise of a painting unknown and unpublished until 2018, which was found in private collection. On the basis of these studies, it was concluded that the painting was most likely created by Pacino di Buonaguida, a Florentine painter and illuminator, active between 1303 and 1340. The depicted scene was identified as The Greeting of Saint Proculus by the Pope. The painting may be linked to a retable attributed to Pacino di Buonaguida and placed inside the church of San Procolo, located in Via de' Giraldo in Florence. This masterpiece constitutes probably a hitherto unknown part of the Legend of Saint Proculus, bishop of Ternia and patron of the church, which belongs to a set of seven representations recognized in the literature so far. All the pieces share the painting style (including characteristic typification of figures and focus on details),
\end{abstract}


iconography, dimensions, technique of execution and framing system. The article also attempts to determine the original location of paintings in the altarpiece, since their shapes and sizes allow for many interpretations and reconstructions. While the most widespread thesis maintains that they formed a predella of the altarpiece, made up of seven scenes, there are indications that the series of the Legend of Saint Proculus was more complex. Assuming the existence of a link between the aforementioned painting and the altarpiece of Saint Proculus in the church of San Procolo in Florence, this work would be the only one created by Pacino di Buonaguida to be found in Polish collections. The identification of an unknown work constitutes an incentive to research the artist's creation, thus significantly altering the existing recognition of the retable situated in the church of San Procolo and opening up new possibilities for its interpretation.

\begin{abstract}
Abstrakt
Artykuł przedstawia wyniki analizy zabytkoznawczej nieznanego i do 2018 r. niepublikowanego obrazu ze zbiorów prywatnych. Na ich podstawie uznano, że malowidło najpewniej jest dziełem warsztatu Pacina di Bonaguidy, florenckiego malarza i iluminatora czynnego w latach ok. 1303-1340, a scenę ukazaną na obrazie zidentyfikowano jako Powitanie św. Prokulusa przez papieża. Obraz ten łączyć można z przypisywanym Pacino di Bonaguidzie retabulum dla kościoła San Procolo przy via de’Giraldo we Florencji - prawdopodobnie jest nieznaną dotąd częścią legendy o św. Prokulusie, biskupie Terni i patronie kościoła, należącą do tej nastawy, liczącej jak dotąd siedem rozpoznanych w literaturze przedstawień. Wszystkie kwatery łączy styl malarski (w tym charakterystyczna typizacja postaci i opracowanie detali), ikonografia, wymiary, technika wykonania i system obramień. W artykule podjęto również próbę ustalenia pierwotnego umiejscowienia malowideł w nastawie ołtarzowej, ich kształty i rozmiary pozwalają bowiem na wiele interpretacji i rekonstrukcji. Według najbardziej rozpowszechnionej tezy tworzyły one predellę retabulum zbudowaną z siedmiu przedstawień, lecz są przesłanki pozwalające zakładać, że cykl legendy o św. Prokulusie był bardziej rozbudowany. Jeśli przyjąć związek prezentowanego obrazu z retabulum św. Prokulusa z kościoła San Procolo we Florencji, byłby on jedynym dziełem Pacina di Bonaguidy w zbiorach polskich. Identyfikacja nieznanego dotąd obrazu stanowi asumpt do badań nad twórczością mistrza, w istotny sposób zmienia też dotychczasowe rozpoznanie retabulum z San Procolo i otwiera nowe możliwości jego interpretacji.
\end{abstract}

W latach 2011-2019 w Zakładzie (obecnej Katedrze) Konserwacji Malarstwa i Rzeźby Polichromowanej UMK w Toruniu był poddawany zabiegom konserwatorskim niewielki obraz tablicowy ze zbiorów prywatnych, noszący cechy stylowe charakterystyczne dla malarstwa Trecenta (il. 1-2). Działania konserwatorskie dały wyjątkową okazję do przeprowadzenia studiów zabytkoznawczych opartych na szczegółowej autopsji, a także integrujących wyniki 
badań nad technologią i techniką wykonania dzieła oraz analizy styloznawczej, kostiumologicznej i ikonograficznej, zawartych w pracy magisterskiej sfinalizowanej przez autorkę w 2016 roku$^{1}$. Rezultaty tych kompleksowych studiów doprowadziły do wniosku, że malowidło jest najpewniej oryginalnym dziełem włoskim, powstałym w latach 1305-1320 we Florencji, a jego autorem jest Pacino di Bonaguida. Ustalenie to zostało przedstawione przy okazji pierwszego i jedynego jak dotąd upublicznienia obrazu na wystawie „Włochy w Gdańsku” zorganizowanej przez Muzeum Narodowe w Gdańsku (Oddział Zielona Brama) i trwającej od 23 września do 31 grudnia 2018 roku². W niniejszym artykule szczegółowo omówiono podstawy tej identyfikacji.

Obraz namalowany został temperą na desce topolowej ${ }^{3}$ o grubości $9 \mathrm{~mm}$. Pole obrazowe o kształcie poziomego prostokąta ze ściętymi narożami (o wymiarach 21,2 cm $\times 31,2 \mathrm{~cm}$ ) ujęte jest w wąską bordiurę o barwie ciemnej, oliwkowej zieleni i jasne obramienie; w narożniki deseczki wmalowane są niewielkie, czerwone trójkątne pola, zdobione złoconym ornamentem roślinnym. Malowidło przedstawia scenę hagiograficzną - powitanie świętego, odzianego w szatę o cechach habitu, z aureolą wokół głowy, przez papieża w stroju pontyfikalnym (w intensywnie czerwonym ornacie, spiczastej tiarze papieskiej z jednym diademem i w białych rękawicach pontyfikalnych), któremu towarzyszą czterej młodzi mężczyźni w świeckich strojach odpowiadających modzie pierwszej ćwierci XIV wieku ${ }^{4}$ po lewej stronie oraz brodaty kapłan stojący po prawej stronie. Scena została ukazana w przestrzeni potraktowanej sumarycznie - pozioma linia gzymsu i rozpięta poniżej kotara, zajmująca całą szerokość pola obrazowego, mogą sugerować wnętrze. Górny pas pola obrazowego, powyżej gzymsu, wypełniony jest złoceniem. Kompozy-

1 Artykuł powstał na podstawie wyników badań prowadzonych w ramach seminarium dyplomowego na kierunku ochrona dóbr kultury w Toruniu, zob. Jagoda Marciniak, „Nieznane dzieło doby Trecenta z kolekcji prywatnej. Analiza zabytkoznawcza” (praca magisterska, Uniwersytet Mikołaja Kopernika w Toruniu, 2016).

2 Zob. Jagoda Marciniak, „Pacino di Bonaguida (czynny w latach ok. 1303-1340) z warsztatem: Powitanie św. Prokulusa z papieżem," w Włochy w Gdańsku, red. Marcin Kaleciński, t. 2 Katalog zabytków (Gdańsk: Muzeum Narodowe, 2019), 46-48.

3 Gatunek drewna, przez poddanie próbek analizom mikroskopowym, zidentyfikował na potrzeby pracy magisterskiej prof. Tomasz Ważny z Zakładu (obecnej Katedry) Technologii i Technik Malarskich UMK w kwietniu 2016 r., za co pragnę serdecznie podziękować.

4 Towarzysze świętego są odziani w obszerne szaty sięgające kostek, o rozszerzających się rękawach długości 3/4, spod których widać długie, obcisłe rękawy szaty spodniej w tej samej barwie. Mężczyzna w różowej szacie nosi płaszcz spięty pod szyją, mężczyzna w czerwonej szacie i wierzchnim okryciu z kapturem ma na głowie biały czepek odkrywający wałek włosów nad czołem i nad karkiem. 
cja jest zamknięta, statyczna, oparta na kierunkach pionowych i poziomych, podporządkowana zasadzie izokefalizmu i zrytmizowana. Charakterystyka postaci, choć dość drobiazgowa, wykazuje tendencję do typizacji ${ }^{5}$; gestykulacja wszystkich figur jest mało wyrazista, sztywna, nieco teatralna, a mimika twarzy powściągliwa. Delikatny i miękki modelunek światłocieniowy wydobywa plastykę fałd szat. Wyeksponowanie krawędzi strojów i konturów sylwetek szerokim, ciemnym obrysem wprowadza efekt linearyzmu i daje wrażenie płaszczyznowości. Gama kolorystyczna jest wąska, ogranicza się do kilku barw różnicowanych tonalnie. Farba nie jest kładziona gładko, w partiach twarzy i szat widać ślady pociągnięć pędzla ${ }^{6}$. Całość, szczególnie z powodu ograniczonej kolorystyki i ekspresji postaci, wywołuje wrażenie statycznej harmonii.

Obiekt był co najmniej czterokrotnie poddawany zabiegom konserwatorskim $^{7}$, lecz znana jest dokumentacja jedynie ostatnich zabiegów, wykonanych w 2011 roku$^{8}$ i kontynuowanych w latach 2015-20199. Warstwa malarska zachowała się w stanie dobrym - jest wprawdzie spękana (il. 3), ale ubytki, także zaprawy, widoczne są jedynie na brzegach. Nie ma wątpliwości, że pierwotne wymiary podobrazia uległy zmianie - obiekt stanowi najpewniej jedynie fragment większej całości. Obraz był też prawdopodobnie wtórnie ścieniany, na co wskazuje zarówno bardzo cienka deska podobrazia (il. 4: a, b), jak i poprzecinane kanały pozostawione przez szkodniki. Wydaje się, że omawiane dzieło mogło być fragmentem predelli, którą zdemontowano, pocięto na mniejsze kawałki (prawdopodobnie dla zmniejszenia ich wagi, a co za tym idzie - ułatwienia ich transportu) i rozprzedano.

5 Postaci są poddane silnej typizacji - zarówno ich pozy, jak i budowa anatomiczna (duże głowy, szerokie ramiona, nienaturalnie małe stopy, długie ręce o małych dłoniach z wąskim śródręczem i długimi palcami) oraz idealizujące cechy fizjonomii (lekko pociągłe oblicza o nieskomplikowanych rysach, wysokie czoła, małe uszy, duże, proste nosy, blisko osadzone, nienaturalnie wąskie migdałowe oczy).

6 Fakturę warstwy malarskiej można zaobserwować w świetle bocznym, grubszą warstwą nakładano kontury szat i ich pofałdowań.

7 Współcześnie dwukrotnie. Informacje o starszych konserwacjach, na podstawie interpretacji wyników badań fotografii fluorescencji UV oraz reflektografii IR, uzyskałam podczas konsultacji z prof. Jarosławem Rogóżem, kierownikiem Zakładu (obecnej Katedry) Technologii i Technik Malarskich (20 VIII 2015 r.), za co składam serdeczne podziękowania.

8 Zob. Jacek Olender, „Powitanie świętego Bernarda przez Innocentego III, I poł. XIV w. Obraz temperowy na desce. Dokumentacja prac konserwatorskich i restauratorskich" (dokumentacja konserwatorska, Toruń 2011, Katedra Konserwacji Malarstwa i Rzeźby Polichromowanej UMK, nr 1506).

9 Jacek Olender, Elena Teodora Necula, i Adam Kaźmierczak, „Dokumentacja prac konserwatorskich i restauratorskich nr 1506” (dokumentacja konserwatorska, Torun 2018, Katedra Konserwacji-Restauracji Malarstwa i Rzeźby Polichromowanej UMK, nr 1506). 
Dla ustalenia stopnia autentyczności obrazu i wykazania, czy i w jakim zakresie został namalowany zgodnie $\mathrm{z}$ warsztatowymi zasadami charakterystycznymi dla tablicowego malarstwa XIV wieku, konieczne były badania porównawcze techniki i technologii wykonania. Wnikliwa analiza wizualna zabytku została wsparta interpretacją wyników badań nieniszczących, wykonanych przy okazji prac konserwatorskich. Do 2016 roku dzieło zostało przebadane za pomocą wielkoformatowego skanera fluorescencji rentgenowskiej (makroXRF) ${ }^{10} \mathrm{w}$ celu uzyskania wizualizacji rozkładu pierwiastków wchodzących w skład pigmentów tworzących warstwy oryginalne i wtórne; wykonano również fotografię fluorescencji lica obrazu wzbudzonej promieniowaniem ultrafioletowym oraz reflektografię w podczerwieni ${ }^{11}$. Wnioski płynące z obserwacji wizualnej i badań technologicznych zabytku można wesprzeć informacjami zawartymi w podręczniku dla malarzy pióra florenckiego mistrza Cennina Cenniniego (1370-1440) ${ }^{12}$, będącym - jak stwierdził Bohdan Marconi - „najważniejszym źródłem wiedzy o technikach malarskich przełomu średniowiecza i wczesnego Renesansu" ${ }^{\prime 3}$.

Omawiany obraz został wykonany zgodnie z charakterystycznymi dla pracowni malarskich Italii warsztatowymi zasadami obowiązującymi w tablicowym malarstwie gotyckim. Jak wspomniano, namalowano go na podobraziu z drewna topoli, a więc jednego z trzech gatunków (obok lipy i wierzby) wymienionych w traktacie Libro dell'arte ${ }^{14}$. Podobrazie to było odpowiednio przygotowane - przeklejone w całości płótnem lnianym ${ }^{15}$ oraz zagruntowane,

10 Pomiary przeprowadzili prof. Piotr Targowski z Instytutu Fizyki UMK i prof. Magdalena Iwanicka z Wydziału Sztuk Pięknych UMK. Za interpretację badań wykonanych za pomocą wielkoformatowego skanera fluorescencji rentgenowskiej, a także informacje z nią związane, pragnę podziękować prof. Mirosławowi Wachowiakowi z Zakładu (obecnej Katedry) Konserwacji i Restauracji Sztuki Nowoczesnej.

11 Fot. Waldemar Grzesik. Interpretację dokumentacji we fluorescencji wzbudzonej UV oraz reflektografii IR, a także informacje z nimi związane, przedstawiam na podstawie wspomnianej konsultacji z prof. Jarosławem Rogóżem.

12 Korzystałam z polskiego tłumaczenia opartego na trzecim wydaniu podręcznika opracowanym w 1913 r. przez Renza Simiego: Cennino Cennini, Rzecz o malarstwie (Florencja: Florencka Oficyna Tyszkiewiczów, 1933).

13 Bohdan Marconi, ,Znaczenie traktatu Cenniniego w historii technik malarskich,” w Cennino Cennini, Rzecz o malarstwie, tłum. Samuel Tyszkiewicz (Wrocław: Ossolineum, 1955), XVI.

14 Cennini, Rzecz o malarstwie, 61.

15 Na brzegach warstwy malarskiej widoczne są ubytki, jeden z nich, w lewym dolnym narożniku obrazu, odsłonił płócienne pokrycie deski, materiał wstępnie rozpoznano jako lniany. Zob. Olender, „Powitanie świętego Bernarda;” Olender, Kaźmierczak, i Necula, „Dokumentacja,” 13 - autorzy opisali nitki jako Z-skrętne, zidentyfikowali też klej glutynowy. 
zgodnie z zaleceniami Cenniniego ${ }^{16}$. Kolejność wykonywanych prac $^{17}$ również odpowiada wskazówkom podanym w Libro dell'arte. Pierwszym etapem było położenie złoceń w górnym pasie kompozycji oraz w partii nimbu świętego, w obrębie miejsc wcześniej zaznaczonych przez autora rytami ${ }^{18}$ (il. 5: a, b). Zdjęcia przekrojów próbek ${ }^{19}$ wykazały, że pod złoceniami znajduje się bardzo cienka warstwa pomarańczowego pulmentu ${ }^{20}$. Autor obrazu najpewniej zdecydował się na jedną z dwóch zalecanych przez Cenniniego metod wykończenia złocenia, tj. na odcięcie złotych elementów za pomocą obrysowania ich blejwajsem (bielą ołowiową) wymieszanym z klejem ${ }^{21}$. Złocenia zostały też wypolerowane i partiami udekorowane. Następnie malarz naniósł czarną farbą rysunek przygotowawczy, w nieznacznych partiach uwidoczniony na zdjęciach mikroskopowych fragmentów obrazu wykonanych po usunięciu wtórnych warstw podczas ostatnich prac konserwatorskich w 2019 roku $^{22}$. Po nałożeniu złoceń i wstępnym zarysowaniu kształtów namalował tło przedstawienia, a także partie jasnego tła poza ciemnozielonym obramieniem głównej sceny oraz ścięte czerwone naroża, ozdobione ornamentem roślinnym. Najpewniej dopiero po tej czynności obwiódł całą kompozycję ciemnozieloną,

16 Cennini, Rzecz o malarstwie, 62-65. Nie jest obecnie możliwe ustalenie, czy zabieg ten przeprowadzono używając zalecanych przez autora traktatu pasów płótna, zob. Cennini, Rzecz o malarstwie, 62. Ze względu na małe rozmiary obrazu nie można wykluczyć, że deseczka została pokryta jednym pasem materiału podczas przygotowywania większego podobrazia.

17 Prześledzenie kolejnych etapów pracy nad obrazem umożliwiła analiza w świetle widzialnym - rozproszonym oraz skośnym.

18 Na powierzchni obrazu widoczny jest obrys wokół nimbu świętego oraz linia ryta ostrym narzędziem wzdłuż krawędzi złotej powierzchni u góry kompozycji - malarz postąpił w ślad za autorem traktatu, który zalecał, by wydrapać iglicą kontury powierzchni, którą chce się później pozłocić (Cennini, Rzecz o malarstwie, 67). Pozłocone, ale nieobrysowane, są drobne detale korony zdobiącej tiarę papieską, być może dlatego, że te elementy nie zostały pokryte złotem płatkowym, lecz proszkowym. Na podstawie mapowania pigmentu złota stwierdzono, że autor dzieła używał głównie złota płatkowego (badanie uwidoczniło pod warstwą farby ślady złota płatkowego, jedynie w elementach tiary papieża jest to złoto proszkowe).

19 Interpretację fotografii przekrojów próbek, a także informacje z nią związane, zawdzięczam konsultacji z prof. Mirosławem Wachowiakiem z Zakładu (obecnej Katedry) Konserwacji i Restauracji Sztuki Nowoczesnej (1 VI 2016 r.), za co składam serdeczne podziękowania.

20 Cennini (Rzecz o malarstwie, 70) zalecał użycie czerwonobrązowej glinki ormiańskiej, ale w okresie Trecenta używano także pomarańczowego oraz białego bolusu, zob. Arleta Tylewicz, Sztuka pozłotnictwa i inne techniki zdobienia (Poznań: eMPi2, 2007), 12.

21 Do takiego wniosku doprowadziły złocenia prześwitujące spod cienkiej warstwy malarskiej w okolicach nimbu świętego, a także analiza badań XRF pod kątem występowania złota; interpretację badań wykonanych za pomocą wielkoformatowego skanera fluorescencji rentgenowskiej, a także informacje z nią związane uzyskałam dzięki konsultacji z prof. Mirosławem Wachowiakiem (23 III 2016 r.).

22 Olender, Nacula, i Kaźmierczak, „Dokumentacja,” 13-14. 
wąską ramą ${ }^{23}$. W kolejnym etapie udekorował tkaninę (być może równocześnie z namalowaniem szat postaci oraz obuwia), a później wykończył szczegóły odzienia ${ }^{24}$. Stroje, z wyjątkiem czerwonych szat, podmalowane zostały odcieniem podstawowym oraz wymodelowane ciemniejszym i jaśniejszym tonem, a w niektórych punktach dodatkowo nałożono na nie bliki niemalże czystej bieli, co również odpowiada zaleceniom Cennina Cenniniego ${ }^{25}$. Załamania materiału są podkreślone grubymi, ciemnymi konturami ${ }^{26}$. Wykończenie to nie dotyczy czerwonych szat, które podmalowane zostały jaśniejszym tonem, a następnie wymodelowane czerwonym laserunkiem ${ }^{27}$. Dzięki takiemu zabiegowi spod warstwy żywicznej widoczna jest barwa spodnia, co daje efekt większej głębi. W dalszej kolejności namalowane zostało wykończenie kotary ${ }^{28}$. Później malarz przystąpił do wykonania partii karnacji ${ }^{29}$, które - również zgodnie ze wskazówkami Cenniniego - podobnie jak szaty wymodelował trzystopniowo, a niektóre ich fragmenty (na przykład czubki nosów, okolice brwi) dodatkowo podkreślił białymi blikami ${ }^{30}$; blejwajsem wykończył także gałki oczne. Wszystkie elementy twarzy oraz palce u dłoni postaci obwiódł ciemniejszym konturem ${ }^{31}$. Prawdopodobnie nie zastosował verdaccio, które renesansowy teoretyk zalecał kłaść pod partiami karnacji ${ }^{32}$.

23 Wniosek na podstawie analizy dzieła w świetle bocznym.

24 Świadczą o tym brzegi szat zachodzące na ornamenty zdobiące draperię w tle oraz na obuwie.

25 Cennini zalecał tonowanie szat trzema odcieniami tej samej barwy: najpierw powinien być użyty odcień pośredni, następnie najciemniejszy dla podkreślenia cieni, na końcu rozbielony przez zmieszanie pigmentu z blejwajsem, Cennini, Rzecz o malarstwie, 44-45, 79.

${ }_{26}$ Te pogrubione kontury zdają się odstawać od reszty warstwy malarskiej - są grubsze, bardziej wypukłe, sprawiają wrażenie namalowanych z mniejszym wyczuciem, co nasuwa podejrzenie o ich wtórność.

${ }^{27}$ Kontury tych partii ubiorów są mniej wypukłe od pozostałych, a także pokryte siatką drobnych krakelur - ich przyczyną są inne właściwości fizyczne laserunku.

28 Wskazuje na to fotografia obrazu w świetle bocznym - można na niej zobaczyć, że na warstwę wykończeniową szat nachodzą bordiury tkaniny zawieszonej w tle, ozdobione kremowym geometrycznym ornamentem.

29 Świadczą o tym wypukłości farby w partii twarzy i dłoni nachodzące na szaty mężczyzn, zauważalne w świetle bocznym.

30 Cennini zalecał modelować twarz trzema odcieniami, aż do zaznaczenia obszaru nad brwiami i czubka nosa czystym blejwajsem. Cennini, Rzecz o malarstwie, 82.

31 Autor Il libro dell'arte polecał obwieść oczy czernią, zaznaczając rzęsy, oraz zarysować nozdrza, Cennini, Rzecz o malarstwie, s. 42; natomiast na omawianym obrazie obrys oczu i nozdrzy wykonano barwą brązową, która nie kontrastuje z kolorem karnacji - dzięki temu zabiegowi malarz uniknął efektu linearnej płaskości.

32 Verdaccio - mieszanka ziemi zielonej oraz blejwajsu, którą należało rozrabiać z żółtkiem „kury miastowej” (Cennini zwracał uwagę, że te żółtka są bledsze niż w jajach kur wiejskich). 
Następnie okonturował elementy karnacji33 oraz namalował włosy postaci, których wykończenie, szczególnie widoczne u starszego duchownego (il. 6), jest zgodne z zaleceniami Cenniniego ${ }^{34}$. Potem wykonał stułę na ramionach starszego człowieka oraz rękawice i tiarę papieską. Wydaje się, że krzesło widoczne po prawej stronie obrazu pojawiło się w końcowym etapie pracy lub domalowano je w późniejszym czasie ${ }^{35}$.

Opisana technika wykonania odpowiada wskazaniom Cennina Cenniniego - malarz najpierw odpowiednio przygotował podobrazie, następnie wykonał złocenia i kolejno malował tło, szaty, a dopiero na końcu karnacje oraz ich wykończenie - tak jak zalecał włoski autor ${ }^{36}$. Efektem wyraźnie niezamierzonym wydają się zacieki farby u dołu obrazu (il. 7). Mogą one wskazywać, że obraz był malowany w pozycji pionowej bądź został postawiony niedługo po namalowaniu, kiedy farba jeszcze odpowiednio nie zgęstniała ${ }^{37}$.

Analiza wyników badań nieinwazyjnych nie przyniosła żadnych niepokojących wniosków co do autentyczności dzieła. Spektroskopia fluorescencji rentgenowskiej nie wykazała niczego, co mogłoby kwestionować autentyczność zastosowanych materiałów malarskich. Chociaż badanie XRF wykrywa wyłącznie pierwiastki, już w 2016 roku można było z pewną dozą prawdopo-

Teoretyk podkreślał też, że choć obraz wymaga wielu warstw malarskich, spod karnacji zawsze musi w pewnym stopniu prześwitywać zieleń. Verdaccio miało służyć również do wykonania cieniowania, zob. Cennini, Rzecz o malarstwie, 81-82.

33 Jako ostateczne wykończenie partii figuralnych Cennini zalecał obwiedzenie elementów karnacji: twarzy, nóg i rąk konturem - ale nie czystą czernią, lecz jej „ździebełkiem” dodanym do ciemnej synopii, Cennini, Rzecz o malarstwie, 82 . Wskazówka ta odpowiada metodzie przyjętej przez autora omawianego obrazu.

34 Siwe włosy duchownego w różowej szacie, namalowane jako jasnoszara plama, zostały wymodelowane przez naniesienie pojedynczych pasemek bielą lub bardzo jasnym odcieniem szarości, zob. Cennini, Rzecz o malarstwie, 42.

35 Świadczą o tym zgrubienia warstwy malarskiej; ponadto przez cienko malowaną draperię na krześle przebija wymalowana wcześniej stuła starszego duchownego.

36 Teoretyk radził, by zawsze najpierw malować szaty i budynki, a dopiero później twarze, zob. Cennini, Rzecz o malarstwie, 79.

37 Zgodność postępowania autora obrazu z zaleceniami teoretyka mógłby potwierdzać fragment polskiego przekładu podręcznika - w rozdziale „Jak się maluje obrazy i jak się rozrabia farby” znajduje się zdanie: „Postaw potem swój obraz przed sobą i zawsze go trzymaj przykryty prześcieradłem”, zob. Cennini, Rzecz o malarstwie, 79. Jednak w oryginalnym tekście Il libro dell'arte odpowiednie słowa nie wskazują jednoznacznie na pionowe ustawienie obrazu: „Poi ti reca la tua ancona innanzi: e sempre fa'che con lenzuolo la tegni converta”, zob. Cennino Cennini, Il libro dell'arte: Trattato della pittura di Cennino Cennini, di nuovo publicato con molte correzioni e coll'aggiunta di piu capitoli tratti dai codici Fiorentini pre cura di Caetano e Carlo Milanesi (Firenze: Le Monnier, 1859), 99. 
dobieństwa określić użyte pigmenty ${ }^{38}$ : minię ołowiową ${ }^{39}$, cynober ${ }^{40}$, ziemne pigmenty żelazowe ${ }^{41}$, żywiczan miedzi ${ }^{42}$, czerwień organiczną (laserunek) ${ }^{43}$, nie wykluczano także wykorzystania zieleni malachitowej ${ }^{44}$ oraz azurytu ${ }^{45}$. Można więc uznać, że żaden z wykazanych pigmentów nie podważa czternastowiecznej metryki omawianego zabytku.

Istotne wnioski dla atrybucji dzieła przynosi analiza styloznawcza ${ }^{46}$. Badany obraz ma jednoznaczne cechy malarstwa włoskiego. Takie właściwości formy, jak budowanie płytkiej głębi z próbą wyznaczenia przestrzeni za pomocą elementów architektonicznych, oszczędność dekoracji i ograniczone użycie złota, klarowny rytm i jasna struktura jednoplanowej i luźnej kompozycji, wąska paleta barw bez kontrastów kolorystycznych, stonowany światłocień (ze światłem skoncentrowanym na postaciach przedstawionych na pierwszym planie) i częściowe eliminowanie konturu ${ }^{47}$, powściągliwa ekspresja postaci, a także ich typika - stylizacja twarzy, proporcje, kostiumy $^{48}$ -

38 Specjalistyczną interpretację zawdzięczam prof. Mirosławowi Wachowiakowi.

39 Na powierzchni pomarańczowej kotary stwierdzono silne stężenie ołowiu.

40 Na innych elementach przedstawienia o barwie czerwonej (szata papieża i jednego z uczniów, trójkątne narożniki obramienia obrazu) stwierdzono duże stężenie rtęci oraz stosunkowo niskie stężenie żelaza.

${ }^{41}$ W partiach włosów postaci, a także w obramieniach ich karnacji oraz w odkrytej części krzesła stwierdzono wysokie stężenie żelaza.

42 W zielonkawych elementach przedstawienia (szaty świętego oraz jego towarzyszy, diadem tiary papieskiej, sukno położone na krześle, ozdobne bordiury kotary, a także ciemnozielone obramienie sceny) wykryto miedź, w najwyższym stężeniu na cieniowaniu szat i tkaninach. Widoczne na mapowaniu tego pierwiastka zmienne stężenie odpowiada pociągnięciom pędzla i jest charakterystyczne dla farb żywicznych. Można zatem przypuszczać, że malarz użył żywiczanu miedzi, na co wskazuje także laserunkowy charakter tego pigmentu oraz jego tendencja do ciemnienia (elementy zielonkawe na obrazie są mocno pociemniałe, miejscami wydają się czarne).

43 W partiach czerwonych szat; na użycie czerwieni organicznej wskazuje występowanie wapnia w miejscach największej intensywności barwy czerwonej.

44 W partiach szat występuje niższe stężenie miedzi.

45 W 2018 r. zdjęto pożółkły werniks, który powodował błędne wrażenie zielonego pigmentu, odsłaniając odcienie błękitu na szatach jednego z towarzyszy świętego.

46 Pełna argumentacja, wraz ze szczegółami badań nad techniką i technologią obrazu, zob. Marciniak, „Nieznane dzieło,” 8-28.

47 Kontury szat są na omawianym obrazie dość grube, ale nie kontrastują z ich ciemnymi kolorami i są raczej próbą nadania im większej plastyczności. Obrys szat czerwonych, a także twarzy i dłoni poprowadzono w ciemniejszych tonach odpowiednich barw, by nie odcinały się mocno od reszty przedstawienia.

48 Stroje towarzyszy świętego przypominają świecką odzież noszoną w Italii w 1. poł. XIV w. Maria Gutkowska-Rychlewska, Historia ubiorów (Wrocław-Warszawa-Kraków: Zakład Narodowy im. Ossolińskich, 1968), il. 205c, 169, określiła analogiczny strój jako „włoskie okrycie męskie z lat 1333-1339". 
przemawiają za tym, że autor dzieła tworzył je według zasad artystycznych znamiennych dla malarskiej szkoły florenckiego Trecenta w orbicie wpływów Giotta. Szczegółowa analiza porównawcza z szeroko ujętym oeuvre malarstwa florenckiego, w tym licznych naśladowców i epigonów mistrza czynnych we Florencji w pierwszej ćwierci XIV wieku, pozwala dostrzec istotne zbieżności analizowanego obrazu z twórczością Pacina di Bonaguidy, aktywnego w latach około 1303-1340. Jest ona nacechowana, oprócz inspiracji dziełami Giotta, również wpływami tzw. Mistrza św. Cecylii i szkoły sieneńskiej ${ }^{49}$, wyraźne są w niej też konserwatywne echa tradycji Duecenta. Wnikliwa analiza porównawcza omawianego malowidła z dziełami Pacina di Bonaguidy pozwala przyjąć, że jest ono w znacznej mierze zbliżone do dorobku tego artysty, zarówno pod względem technologicznym, jak i stylistycznym. Trzeba zaznaczyć, że sposób malowania Pacina istotnie odbiegał od metod pracy innych „uczniów” Giotta, artysta ten bowiem był przede wszystkim miniaturzystą, co miało niebagatelny wpływ na jego styl malarski. Iluminatorska maniera malarska Pacina, jaką stosował także w swych obrazach tablicowych, jest niezwykle istotna dla rozpoznania źródła stylu omawianego zabytku. Jego twórczość wykazuje znacznie mniej monumentalizmu niż dzieła innych malarzy florenckich w tym czasie, silniej też tkwi w tradycji Duecenta, zachowując płaskość plam i decydującą rolę konturu. Malowane przez Pacina postaci charakteryzują się smukłą, „rachityczną” budową, ich duże głowy dominują nad szczupłymi korpusami. Indywidualną cechą wydają się dłonie: wydłużone, smukłe, o bardzo wąskich nadgarstkach i długich palcach, które powtarzają się u wszystkich przedstawianych przez niego postaci (il. 8). Znamienne są także nieznacznie tylko zróżnicowane typy twarzy - lekko wydłużone, o wysokich czołach, wąskich, blisko osadzonych oczach, prostych mocnych nosach i krótkich bladych ustach ${ }^{50}$.

Oprócz pojawiających się na wszystkich miniaturach autorstwa Pacina di Bonaguidy swoistych cech postaci, na niektórych z nich można dostrzec analogiczne do omawianego obrazu szczegóły. Należą do nich: stroje (powta-

49 Maria Skubiszewska, Malarstwo Italii w latach 1250-1400 (Malarstwo Europejskie w Średniowieczu, t. 4) (Warszawa: Auriga, 1980), 72.

50 Na większości prac malarskich Pacina postaci mają podobne fizjonomie o charakterystycznych cechach, takie jak np. na tryptyku i dyptyku ze zbiorów The Alana Collection w Delaware, zob. szerzej Marciniak, „Nieznane dzieło”, 55-59. 
rzają się elementy ubioru) ${ }^{51}$, fryzury i nakrycia głowy ${ }^{52}$, nimby zdobione puncyną kulkową oraz rytowanymi, cienkimi promieniami ${ }^{53}$, kotara zawieszona w tle sceny, dekorowana delikatnym ornamentem i opatrzona wyróżniającą się, kontrastującą kolorem bordiurą z geometrycznym zdobieniem ${ }^{54}$, ujęcie przedstawienia biegnącą wokół niego bordiurą dekorowaną geometrycznym wzorem $^{55}$. Typowy dla jego maniery jest sposób modelowania szat o ograniczonej ilości pofałdowań, które podążają za ruchem ciała ${ }^{56}$, a także cieniowanie za pomocą kreseczkowania ${ }^{57}$, czym również cechuje się omawiane przedstawienie.

Dzięki temu, że dorobek Bonaguidy w 2012 roku doczekał się badań technologicznych ${ }^{58}$, możliwe było porównanie omawianego obrazu z jego

51 Szata świętego jest identyczna z odzieniem bł. Gerarda z Villamagna w „The Morgan Codex”, najlepiej jest to widoczne na dolnej scenie fol. 35 (w zbiorach The Morgan Library \& Museum). Podobne szaty z długimi wąskimi rękawami Pacino namalował na miniaturze przedstawiającej tronującą świętą Agnieszkę oraz sceny z jej życia zamieszczonej w „Laudario” wykonanym dla Towarzystwa Świętej Agnieszki w Carmine (w zbiorach The British Library w Londynie, nr inw. Add. Ms. 18196), a także w kopii „Novella commentaria in libros I-II Decretalium" autorstwa Giovanniego d'Andrei (w zbiorach Biblioteca Apostilica Vaticana), w scenie przekazania księgi papieżowi.

52 Np. zbliżony zarost mają jeden $\mathrm{z}$ apostołów w scenie Ostatniej Wieczerzy w „The Morgan Codex" i brodaty kapłan. Identyczne fryzury i nakrycia głowy widać na miniaturach, np. na dolnej scenie fol. $35 \mathrm{z}$ „The Morgan Codex”, na wspomnianej iluminowanej karcie w „Novella commentaria in libros I-II Decretalium”, na pochodzącej z „Laudario” miniaturze przedstawiającej św. Jana Ewangelistę na Patmos, umieszczonej w inicjale „G” (w zbiorach Free Library of Philadelphia, nr Lewis E M 25:7a). Tiara papieska z diademami jest namalowana w ten sam sposób na omawianym obrazie i na miniaturze przedstawiającej wyznawców w rękopisie „Carmina regia” (w zbiorach The British Library w Londynie), w kopii „Novella commentaria in libros I-II Decretalium".

53 Np. na florenckim obrazie Drzewo Życia (w zbiorach Accademia di Belle Arti we Florencji).

54 Nimb malowany w taki sposób można zobaczyć m.in. na iluminacji ukazującej klęczącą Matkę Bożą w rękopisie „Carmina regia” (w zbiorach The British Library w Londynie), w scenie przekazania księgi papieżowi w kopii „Novella commentaria in libros I-II Decretalium”.

55 Np. miniatury z Męczeństwem św. Jakuba Apostoła Większego oraz Ścięciem św. Krzysztofa (w zbiorach The Old Library, w Queens' College pod nr. MS 77d i MS 77b) pochodzące z „Laudario”.

56 Zastosowano go m.in. w iluminacji ukazującej Chrystusa w mandorli (w zbiorach National Gallery of Art, Rosenwald Collection w Waszyngtonie, nr inw. 1952.8.277) i na miniaturze ze świętą Agnieszką z „Laudario”.

57 Najlepiej widoczne jest to na iluminowanych kartach „Laudario” oraz na miniaturach w rękopisie „Carmina regia”. Analogie można znaleźć również w malarstwie tablicowym Pacina di Bonaguidy - na florenckim obrazie Drzewo Życia (w zbiorach Accademia di Belle Arti we Florencji).

58 Yvonne Szafran i Nancy Turner, „Techniques of Pacino di Bonaguida, Illuminator and Panel Painter," w Florence at the Dawn of the Renaissance: Painting and Illumination, 1300-1350, red. Christine Sciacca (Los Angeles: J. Paul Getty Museum, 2012), 335-355. 
twórczością także pod tym względem. W trakcie przygotowywania publikacji towarzyszącej wystawie „Florence at the Dawn of the Renaissance: Painting and Illumination, 1300-1350" przebadano trzydzieści jeden prac: dwadzieścia jeden kart iluminowanych manuskryptów i dziesięć dzieł malarstwa tablicowego, w tym siedemnaście iluminacji i siedem malowideł na desce przypisywanych Bonaguidzie ${ }^{59}$. Wyniki tych badań skonfrontowane $\mathrm{z}$ analizą omawianego obrazu ${ }^{60}$ potwierdzają tożsamość warsztatową porównywanych prac. Zostały one w ten sam sposób przygotowane ${ }^{61}$, zastosowano te same pigmenty ${ }^{62}$, w taki sam sposób wykończono szaty oraz karnacje ${ }^{63}$. Porównanie dzieł Pacina i omawianego obrazu pod względem faktury i kolejności kładzenia warstw malarskich jest na razie niemożliwe, badania przeprowadzone przez zespół z Getty Conservation Institute jedynie dotknęły tego zagadnienia, skupiając się głównie na analizie rysunków przygotowawczych.

Sylwetka twórcza Pacina di Bonaguidy jest dość dobrze opracowana w literaturze. Badaczem najobszerniej i najbardziej wnikliwie zajmującym się jak dotąd jego twórczością oraz autorem większości dzisiejszych atrybucji zarówno dzieł tablicowych, jak i miniatorskich, jest Richard Offner (1889-1965). Przeprowadził on dociekliwe studia nad stylem artysty, a swoje ustalenia przedstawił w opracowaniach publikowanych w ciągu kilkudziesięciu lat ${ }^{64}$.

59 Catherine Schmidt Patterson, Alan Phenix, i Karen Trentelman, „Scientific Investigation of Painting Practices and Materials in the Work of Pacino di Bonaguida," w Florence at the Dawn, tab. 2, 361-362.

60 Marciniak, „Nieznane dzieło,” 47-53.

${ }^{61}$ Co prawda warstwy malarskie przeanalizowane przez zespół badaczy z Getty Conservation Institute zostały położone na czerwonym, a nie na pomarańczowym bolusie, lecz nie wyklucza to możliwości wykonania omawianego obrazu przez Pacina, zob. Szafran i Turner, „Techniques of Pacino di Bonaguida,” 341.

62 Na siedem przebadanych dzieł malarstwa tablicowego autorstwa Pacina minię zidentyfikowano w pięciu, biel ołowiową w siedmiu, cynober w siedmiu, ziemie żelazowe w czterech, azuryt w siedmiu, zob. Schmidt Patterson, Phenix, i Trentelman, „Scientific Investigation,” 361-371.

63 Zastosowano tonowanie warstwowe oraz laserunki: na siedem przebadanych dzieł malarstwa tablicowego Pacina zieleń miedziową zidentyfikowano w czterech, czerwień organiczną w sześciu pracach, zob. Schmidt Patterson, Phenix, i Trentelman, „Scientific Investigation," tab. 2, 370.

64 Richard Offner, „Pacino di Bonaguida, a Contemporary of Giotto,” Art in America 11 (1922): 3-27; Richard Offner, Studies in Florentine Painting. The Fourteenth Century (New York: Federic Fairchild Scherman, 1927); Richard Offner, The Fourteenth Century (A Critical and Historical Corpus of Florentine Painting, red. Richard Offner, vol. 3) (New York: College of Fine Arts, New York University, 1930); Richard Offner, Elder Contemporaries of Bernardo Daddi (A Critical and Historical Corpus of Florentine Painting, sec. 3, vol. 2, red. Richard Offner i Klara Steinweg) (New York: Institute of Fine Arts, New York University, 1956), continued 
Przygotowując kilkutomowe zbiorowe wydawnictwo A Critical and Historical Corpus of Florentine Painting - czym zajmował się od 1930 roku do swojej śmierci - współpracował między innymi z Miklósem Boskovitsem, który również wniósł znaczny wkład w badania nad twórczością Pacina. Ważną publikacją jest Painting and Illumination in Early Renaissance in Florence, 1300-1450 autorstwa Laurence'a B. Kantera i Barbary Drake Boehm z 1994 roku ${ }^{65}$, w której Kanter analizuje malarską, a Drake Boehm - iluminatorską działalność Pacina di Bonaguidy. Jedną z najnowszych publikacji dotyczących twórczości tego malarza jest katalog towarzyszący wspomnianej wystawie pt. „Florence at the Dawn of the Renaissance...”66 prezentowanej w Getty Center w Los Angeles od listopada 2012 do lutego 2013 roku oraz w The Art Gallery of Ontario w Toronto od marca do czerwca 2013 roku; zasób zawartych w nim nowych informacji, a także nowatorskie podejście badaczy sprawiają, że wydawnictwo to wnosi niezwykle cenny wkład do badań nad sztuką florenckiego Trecenta. Regularnie publikowane są też studia przyczynkowe na temat miniatorskich prac czternastowiecznego mistrza ${ }^{67}$.

Niewiele faktów dotyczących życia Pacina di Bonaguidy jest dziś znanych $^{68}$, a szczątkowe udokumentowane informacje na jego temat są przez

under the direction of Miklós Boskovits and Mina Gregori, A new edition with additional notes and bibliography by Miklós Boskovits (Florence: Instituto di Storia Dell'Arte of The University of Florence, 1987).

65 Laurence B. Kanter i Barbara Drake Boehm, Painting and Illumination in Early Renaissance in Florence, 1300-1450 (New York: The Metropolitan Museum of Art, 1994).

66 Florence at the Dawn of the Renaissance: Painting and Illumination, 1300-1350, red. Christine Sciacca (Los Angeles: J. Paul Getty Museum, 2012).

67 Np. Pia Palladino, Treasures of a Lost Art: Italian Manuscript Painting of the Middle Ages and Renaissance (New York: Yale University Press, 2003); Francesca Pasut, „Pacino di Bonaguida e le miniature della Divina Commedia: un percorso tra codici poco noti," w Da Giotto a Botticelli: pittura fiorentina tra gotico e Rinascimento: atti del convegno internazionale, Firenze, Università degli studi e Museo di San Marco, 20-21 maggio 2005, red. Francesca Pasut i Johannes Tripps (Firenze: Giunti, 2008), 41-62; Stella Payanotova, „New Miniatures by Pacino di Bonaguida in Cambridge," The Burlington Magazine 151 (2009): 144-147; Daniele Guernelli, „A New Manuscript for Pacino di Buonaguida," Manuscripta: A Journal for Manuscript Research 55, no. 2 (2011): 192-204; Marzia Pontone, „La Bibbia Trivulziana di Pacino di Bonaguida. Note sul riesame dell'allestimento materiale del codice Trivulziano 2139," Libri \& Documenti. Archivio Storico Civico e Biblioteca Trivulziana 39 (2013): 7-25; Francesca Pasut, „La Bibbia Trivulziana di Pacino di Bonaguida. La decorazione miniata del codice Trivulziano 2139: una impresa di équipe," Libri \& Documenti. Archivio Storico Civico e Biblioteca Trivulziana 39 (2013): 27-50.

68 Nazwisko artysty bywa błędnie pisane jako „Buonaguida” - takiej formy używał Richard Offner (Offner, The Fourteenth Century), a za nim wielu badaczy, zob. m.in. Mária Prokopp, Die Malerei des Trecento (Budapest: Corvina, 1986), 32; George Kaftal, Iconography of the Saints 
badaczy różnie interpretowane ${ }^{69}$. Jedynym sygnowanym dziełem tego artysty jest dawny ołtarz główny kościoła San Firenze, przedstawiający Ukrzyżowanie ze świętymi Mikołajem, Bartłomiejem, Florentiuszem i Łukaszem (obecnie w Galleria dell'Accademia we Florencji). Mimo atrybuowanych Bonaguidzie wielu prac, których wykonanie bezsprzecznie wymagało licznego warsztatu ${ }^{70}$, tylko kilka z nich jest dokładnie datowanych, kwestia chronologii jego oeuvre pozostaje więc otwarta ${ }^{71}$ (próbę ustalenia kolejności powstawania jego dzieł podjęła między innymi Christine Sciacca ${ }^{72}$ ). W pracach tego malarza czytelny

in Tuscan Painting (Florence: Sansoni, 1952), 859; Ada Labriola, „Pacino di Buonaguida,” w Dizionario biografico dei miniatori italiani. Secoli IX-XVI (Milano: Sylvestre Bonnard, 2004); zob. też strony Fundacji Zeri oraz British Library.

69 Pacino di Bonaguida pierwszy raz wzmiankowany jest w dokumencie z 20 II 1303 r., tekst zob. Ulrich Thieme i Felix Becker, Allgemeines Lexikon der bildenden Künstler von der Antike bis zur Gegenwart, Bd. 26 (Leipzig: E. A Seemann 1992), 126. Jego treść wskazuje, że był on wtedy szanowanym twórcą, Kanter i Drake Boehm, Painting and Illumination, 45. Początki jego kariery sięgają więc zapewne końca XIII w., Miklós Boskovitz, The Fourteenth Century: The Painters of the Miniaturists Tendency (A Critical and Historical Corpus of Florentine Painting, sec. 3, vol. 9) (Florence: Giunti Barbèra, 1984), 48. Istnieją dwie interpretacje zawartych w dokumencie informacji; zob. Kanter i Drake Boehm, Painting and Illumination, 45. Według pierwszej dokument dotyczy rozwiązania założonej rok wcześniej spółki z nieznanym dziś artystą o imieniu Tambo di Seraglio, zob. Gaetano Milanesi, Nuovi documenti per la storia dell'arte toscana (Firenze: G. Dotti 1901), 44. Według drugiej interpretacji w dokumencie stwierdzono jedynie, że Pacino di Bonaguida zapisał się do cechu malarzy i mieszka w parafii S. Lorenzo, zob. Mirella Levi D’Ancona, Miniatura e miniatori a Firenze dal XIV al XVI secolo: documenti per la storia della miniatura (Firenze: Leo S. Olschki, 1962), 217. Po części Pacina dotyczy XIV-wieczny dokument w Archivio di stato z Medici e Soeziali (znany mi fragmentarycznie za pośrednictwem literatury, zob. Levi D’Ancona, Miniatura e miniatori, 217), potwierdzający przynależność malarza do gildii rzemieślniczej, a konkretnie do organizacji Arte dei Medici e Speziali. Nie jest jasne, jak długo artysta działał w cechu, badacze nie są w tej sprawie zgodni: Karl Frey, Die Loggia dei Lanzi zu Florenz: eine quellenkritische Untersuchung (Berlin: Wilhelm Hertz, 1885), 331, wskazuje na lata1320-1338/1339; Dominic Ellis Colnaghi, A Dictionary of Florentine Painters: from the $13^{\text {th }}$ to the $17^{\text {th }}$ Centuries, red. P. G. Konody i Selwyn Brinton (London: John Lane the Bodley Head, 1928), 196, zawęził ten okres do lat 1320-1328; Levi D’Ancona, Miniatura e miniatori, 217, uważa, że artysta został wymieniony w spisie immatrykulowanych pomiędzy 1327 a 1328 r. Prawdopodobnie w określeniu czasu artystycznej aktywności Pacina we Florencji mogłaby pomóc inskrypcja na poliptyku jego autorstwa z przedstawieniem Ukrzyżowania w asyście Marii i św. Jana Ewangelisty, niestety zachowała się jedynie fragmentarycznie („MCCCX...”, zob. Levi D’Ancona, Miniatura e miniatori, 217). Ostatnia udokumentowana informacja dotycząca twórczości Pacina pochodzi z 1328 r., ale niektórzy badacze twierdzą, że jego aktywność artystyczna sięgała 1339 r. Zdaniem R. Offnera Pacino był dojrzałym artystą już przed pierwszą znaną datą, czyli 1303 r., i działał jeszcze po 1320 r., Offner, Elder Contemporaries, 63.

70 Bryan C. Keene, wprowadzenie do Florence at the Dawn of the Renaissance, 3.

71 Boskovits, The Fourteenth Century, 47.

72 Christine Sciacca, „Pacino di Bonaguida and His Workshop,” w Florence at the Dawn of the Renaissance, 288-295. 
jest nie tylko wyraźny wpływ Giotta i szkoły sieneńskiej, lecz także Mistrza św. Cecylii, którego styl został przez Pacina poddany schematyzacji i sprowadzony do wręcz piktograficznej maniery. Zdaniem Richarda Offnera ekspresja tego artysty niejako wypełnia „pustą” przestrzeń pomiędzy Duecentem a Trecentem ${ }^{73}$. Bonaguida był wiodącym iluminatorem oraz doświadczonym malarzem i osiągnął sukces we Florencji na obu tych polach. Choć dziś jest mniej znany niż inni malarze tworzący we wczesnym Trecencie we Florencji, jak chociażby Giotto i Bernardo Daddi, wielka liczba i kompleksowość jego prac - zarówno malarstwa tablicowego, jak i iluminatorstwa - wskazuje, że był rozchwytywany przez florenckich mecenasów sztuki ${ }^{74}$. Aktywny około pięciu dekad artysta tworzył wszelkiego rodzaju dzieła malarskie, w tym nastawy ołtarzowe w formie dyptyków, tryptyków i poliptyków w różnej skali, krucyfiksy procesyjne i ołtarzowe oraz projekty witraży ${ }^{75}$. Jak podkreśla Christine Sciacca ${ }^{76}$, wielka liczba pozostawionych przez Pacina obrazów tablicowych oraz miniatur wskazuje, że był on w czternastowiecznej Florencji jednym z wiodących twórców i prowadził znaczący warsztat, zatrudniający wielu pracowników.

Dogłębna analiza oeuvre Pacina di Bonaguidy pozwala uznać omawiany obraz ze zbiorów prywatnych za nieznaną dotąd ilustrację legendy o św. Prokulusie, biskupie Terni, należącą najpewniej do jednego zespołu wraz z siedmioma innymi malowidłami, stanowiącymi część przypisywanego temu malarzowi retabulum patronalnego dla kościoła San Procolo przy via de’Giraldo we Florencji. Pięć tablic pozostaje w rękach prywatnych ${ }^{77}$, dwie znajdują się w Fogg Museum należącym do Harvard Art Museums w Cambridge w sta-

Offner, Elder Contemporaries, 63.

74 Sciacca, „Pacino di Bonaguida,” 285.

75 Keene, wprowadzenie, 2.

76 Sciacca, „Pacino di Bonaguida,” 285.

77 Św. Prokulus odprawiający mszę św. - rynek antykwaryczny w Paryżu w 1992 r., zob. Tableaux modernes, tableaux anciens, important mobilier du XVIIIe siècle, tapisseries: vendredi 11 décembre 1992, cat. Drouot Richelieu (Paris, 1992), n. 39, za: „Pacino di Buonaguida, San Procolo celebra la messa alla presenza di un vescovo", Dostęp 14 lipca 2018, http://catalogo.fondazionezeri.unibo.it/scheda/opera/3029/Pacino\%20di\%20Buonaguida\%2C\%20San\%20Procolo\%20celebra\%20la\%20messa\%20alla\%20presenza\%20di\%20un\%20vescovo); Cud u grobu św. Prokulusa - rynek antykwaryczny w Londynie w 2016 r., Dostęp 18 lipca 2018, zob. http:// www.sothebys.com/fr/auctions/ecatalogue/lot.26.html/2016/old-master-british-paintings-evening-116033; Św. Prokulus uzdrawiający dziecięca dłoń - miejsce przechowywania nieznane; Męczeństwo św. Prokulusa - jeszcze w 1984 r. w prywatnej kolekcji w Bergamo; Ścięcie św. Prokulusa - w 1984 r. w kolekcji Cinelli we Florencji, Offner, Elder Contemporaries, 137, 132. 
nie Massachusetts ${ }^{78}$ (il. 9 i 10); omawiany zabytek wydaje się zatem kolejną - ósmą - częścią tego zespołu. Wszystkie te kwatery łączy jednorodny styl malarski (w tym charakterystyczna typizacja postaci i opracowanie detali ${ }^{79}$ ), ikonografia związana ze św. Prokulusem, wymiary ${ }^{80}$, technika wykonania ${ }^{81}$ i system obramień ${ }^{82}$. Przedstawioną na omawianym obrazie scenę, na podstawie wnikliwej analizy legendy tego świętego ${ }^{83}$, można identyfikować jako Powitanie św. Prokulusa przez papieża.

78 Św. Prokulus zatrzymujący łanię $w$ dziczy, nr inw. 1943.110, i Św. Prokulus skłania łanię, by oddała mleko spragnionym towarzyszom, nr inw. 1943.111.

79 M.in. głowa św. Prokulusa, zarówno na omawianym obrazie, jak i na siedmiu malowidłach z tego zespołu okolona jest jednakowym złotym nimbem, zdobionym puncyną kulkową oraz rytowanymi promieniami; w taki sam sposób, tj. za pomocą drobnych i cienkich pociągnięć pędzla opracowano identycznego kształtu brodę o dwóch szpicach u starszego duchownego na obrazie badanym w Toruniu oraz u jednego z oprawców w Męczeństwie św. Prokulusa; ozdobne bordiury szat świętego, biskupa i jego pomocnika w przedstawieniu Cudu u grobu św. Prokulusa są dekorowane w taki sam sposób jak bordiura kotary wiszącej w tle sceny Powitania św. Prokulusa przez papieża.

80 Według informacji na stronie Harvard Art Museums wymiary obu malowideł w Fogg Museum wynoszą ok. $25 \times 34,9 \mathrm{~cm}$; na stronie fundacji Federico Zeri podano, że obraz Św. Prokulus odprawiający mszę św. mierzy 26,2 × 31 (zob. „Pacino di Buonaguida, San Procolo celebra la messa alla presenza di un vescovo”, Dostęp 14 lipca 2018); dom aukcyjny Sotheby's podaje, że dzieło sprzedane w $2016 \mathrm{r}$. w Londynie mierzyło $21 \times 31 \mathrm{~cm}$.

81 Porównanie dzieł w zakresie technologii i stanu zachowania było możliwe dzięki udostępnieniu na potrzeby pracy magisterskiej dokumentacji wykonanej w 2006 r. przez Morwennę Blewett dla Fogg Museum, zob. Morwenna Blewett, „Treatment Report. Accession number: 1943.110" (dokumentacja konserwatorska, Cambridge 2006, Straus Center for Conservation Harvard University Art Museums); Morwenna Blewett, „Treatment Report. Accession number: 1943.111" (dokumentacja konserwatorska, Cambridge 2006, Straus Center for Conservation Harvard University Art Museums). Udostępnienie jej zawdzięczam uprzejmości p. Tary Cerretani z Harvard Museums (Curatorial Assistant for Special Exhibitions and Publications).

82 Wszystkie przedstawienia zamknięte są identycznymi, prawie czarnymi, malowanymi cienką linią ramami w kształcie leżącego prostokąta o ściętych narożach. Po zewnętrznej stronie ram, w narożach deski, widoczne są trójkąty na jasnym tle ozdobione motywem liści (w obrazie toruńskim - po obu stronach czerwone). Kolory trójkątów możemy rozpoznać jedynie na malowidłach, których kolorowe reprodukcje są dostępne, tj. na dwóch obiektach z Fogg Museum oraz obrazie sprzedanym na aukcji w 2016 r.: na kwaterze Św. Prokulus zatrzymujqcy łanię są to czerwone trójkąty po stronie lewej i granatowe po stronie prawej, przy scenie dojenia łani - granatowe po lewej i czerwone po prawej stronie, na obrazie Cud u grobu św. Prokulusa - czerwone trójkąty zarówno po lewej, jak i po prawej stronie.

83 Legenda o św. Prokulusie została wprawdzie opublikowana (po łacinie) na kartach Acta sanctorum - zob. Godefrido Henchenio et al., Acta sanctorum quotquot toto orbe coluntur, vel a catholicis scriptoribus celebrantur quae ex latinis et graecis, aliarumque gentium antiquis monumentis, Junii, t. 1 (Parisiis et Romæ: APUD Victorem Palmé, 1867, 77-80) - jej analizę utrudnia jednak zawiły i sztucznie ukwiecony język, jakiego używali jej kolejni autorzy (była spisywana i uzupełniana od 1643 r. do XX w.). Historię tego świętego w hagiograficznym 
Historię florenckiego retabulum św. Prokulusa omówił w swej pracy z 1956 roku wspomniany wcześniej Richard Offner ${ }^{84}$. Zostało ono prawdopodobnie usunięte z kościoła $\mathrm{w} 1622$ roku z powodu reorientacji przestrzeni i podzielone najpóźniej w 1677 roku, choć predelli nie odnotował już Borghini opisując retabulum w 1584 roku $^{85}$. Uczynił to natomiast w roku 1754 Giuseppe Richa ${ }^{86}$, który cztery kwatery oraz predellę należącą do omawianego poliptyku oglądał w pokoju proboszcza (rektora?) w kościele San Procolo; widząc części nastawy osobno, przypisał poliptyk Giottowi, a predellę Ambrogio Lorenzettiemu. W roku 1778 niektóre partie predelli przekazano najpewniej, wraz z częścią wyposażenia kościoła, do klasztoru w Badii ${ }^{87}$. Pierwotnie $^{88} \mathrm{~W}$ centrum nastawy znajdowało się przedstawienie Madonny (zaginione), flankowane przez półfigury św. Jana Chrzciciela (obraz zaginiony) oraz św. Jana Ewangelisty i dwóch świętych biskupów - Mikołaja i Prokulusa, które utożsamiane są przez Offnera z obrazami przechowywanymi w Galleria dell'Accademia we Florencji ${ }^{89}$.

Nie jest możliwa weryfikacja kolejności ani liczby scen, jakie powinien zawierać cykl przedstawień ukazujący żywot św. Prokulusa biskupa, przez porównanie do innego zabytku o analogicznej tematyce, gdyż dotąd takiego nie odnaleziono. Rozczłonkowane retabulum z kościoła San Procolo we Florencji jest jedyną znaną dziś ilustracją legendy o tym świętym, a to, jakie sceny powinny znaleźć się na predelli, wywnioskować można jedynie na podstawie analizy tej legendy. Scena powitania przez papieża (lub pojednania z papieżem), którą przedstawia omawiany tu zabytek, obrazuje jedno z kulminacyjnych wydarzeń w żywocie św. Prokulusa, oskarżonego przez arian o łamanie prawa kanonicznego, wezwanego do Rzymu i uniewinnione-

ujęciu, ale w sposób jasny i szczegółowy przedstawił w XVIII w. Ercole Maria Zanotti, Storia dei santi Procolo soldato cavalier bolognese, e protettore della sua patria, e Procolo Siro vescovo di Terni ambedue martiri composta e di alcune annotazioni accresciuta da Ercole Maria Zanotti bolognese (Bologna: a S. Tommaso d'Acquino, 1742), 87-120.

84 Te same informacje wraz z komentarzem zob. też Miklós Boskovits i Angelo Tartuferi, Dipinti. Volume primo: Dal Duecento a Giovanni da Milano (Firenze: Giunti, 2003), 215-216 (nota katalogowa autorstwa Isabeli Troconi).

85 Rafaello Borghini, Il riposo, in cui della pittura e della scultura si favella, e' più illustri pittori, e scultori, e delle più famose opere loro si fa mentione, e le cose proncipali appertenenti a dette arti s'insegnano (Fiorenza: Marescotti, 1584), 296-297.

86 Giuseppe Richa, Notizie istoriche delle chiese fiorentine, divise ne'suoi quartieri, vol. 1 (Firenze: Pietro Gaetano Viviani, 1754), 242-243.

87 Offner, Elder Contemporaries, 63.

88 Borghini, Il riposo; Richa, Notizie.

89 Offner, Elder Contemporaries, 137. 
go przez papieża (zapewne Jana ${ }^{90}{ }^{90}$ ). Legenda głosi, że papież - tu ukazany w stroju pontyfikalnym - wybiegł św. Prokulusowi na spotkanie i w akcie skruchy objął go i przytulił do piersi ${ }^{91}$. Prokulus przedstawiony został w szatach przypominających zakonny habit (podobnie jak w innych kwaterach cyklu), towarzyszą mu najpewniej papiescy wysłannicy. Jest to - jak się wydaje - jedyne znane wyobrażenie tego epizodu zachowane do naszych czasów, a czas jego powstania można zawęzić na podstawie datowania innych obiektów z tego samego zespołu malarskiego do lat 1303-1320.

Ustalenie pierwotnego umiejscowienia malowideł - rozproszonych w różnych zbiorach - w nastawie ołtarzowej nie jest dziś w pełni możliwe. Z pewnością należały one do retabulum, w którym znajdowało się osiem lub więcej kwater z przedstawieniem scen z żywota św. Prokulusa. Najbardziej rozpowszechniona, a zarazem najbardziej prawdopodobna teza - sformułowana przez Richarda Offnera ${ }^{92}$ - głosi, że tworzyły one predellę retabulum zbudowaną z siedmiu scen ilustrujących wydarzenia opisane w legendzie. Badacz ten znał pięć z sześciu zidentyfikowanych dziś przedstawień, a swoją opinię oparł na sprawozdaniu, które pozostawił Giuseppe Richa ${ }^{93}$. Jezuita ów opisał w XVIII wieku sześć scen, przy czym nie rozgraniczył dwóch przedstawień cudu z łaniąa94, a ponadto wymienił do dziś nieodnalezioną scenę uleczenia ręki chłopca ${ }^{95}$. Richard Offner twierdził, że widziane przez Richę cztery

90 Z wymienionych przez Zanottiego trzech papieży, którzy mogli wystąpić w tym epizodzie, tj. Eugeniusza I, Sylweriusza oraz Jana II (Zanotti, Storia dei santi Procolo, 102), wykluczyć można Sylweriusza, ponieważ papież przedstawiony na toruńskim obrazie nie ma nimbu, Sylweriusz zaś uznany został za świętego już w XI w., zob. Richard P. McBrien, Leksykon papieży: pontyfikaty od Piotra Apostoła do Jana Pawła II (Warszawa: Świat Książki, 2003), 71-72. Brak nimbu nie pozwala na dalszą identyfikację, gdyż Eugeniusz I został włączony do Martyrologium dopiero na przełomie XV i XVI w. (zob. McBrien, Leksykon papieży, 82-83), Jan II zaś nigdy nie został kanonizowany. Biorąc jednak pod uwagę, że do spotkania obu hierarchów doszło niedługo po objęciu przez Prokulusa biskupstwa, co nastąpiło w 530 r. (Zanotti, Storia dei santi Procolo, 101), a Eugeniusz I był papieżem w latach 654-657 (McBrien, Leksykon papieży, 82), natomiast Jan II w latach 533-535 (McBrien, Leksykon papieży, 71), należałoby przyjąć, że Prokulus witał się z Janem. W legendarnym żywocie świętego występują także elementy fantastyczne, ale $\mathrm{z}$ chwilą objęcia przez niego biskupstwa chronologia zostaje zachowana, co mogą potwierdzać choćby wydarzenia znane z innych źródeł: Prokulus był torturowany i ścięty w 543 lub 546 r. (Zanotti, Storia dei santi Procolo, 116-117) z rozkazu Totili, króla Gotów, który panował od 541 r., zob. Piotr Iwaszkiewicz, Wiesław Łoś, i Marek Stępień, Władcy i wodzowie starożytności. Słownik (Warszawa: WSiP, 1998), 206.

91 Zanotti, Storia dei santi Procolo, 102-108.

92 Offner, Elder Contemporaries, 23-25, il. XXIX (Ad. pl. IV).

93 Richa, Notizie, 242-243.

94 „[...] dei viandanti col latte di una Cerva dal Santo accorsi”, Richa, Notizie, 243.

95 „[...] della mano ad un fanciullo risanata”, Richa, Notizie, 243. 
przedstawienia świętych są częścią retabulum oraz że oprócz centralnego obrazu Madonny z Dzieciątkiem zaginąć musiały jeszcze dwie kwatery poliptyku z wizerunkami świętych. Wnioski te wysnuł na podstawie liczby scen predelli - założył mianowicie, że nad siedmioma scenami znajdowało się również siedem przedstawień półpostaciowych o analogicznej szerokości. Badacz zaproponował następującą kolejność obrazów w predelli (licząc od lewej): Św. Prokulus odprawiający mszę św., dwa malowidła ukazujące cud z łanią, Uleczenie ręki chłopca (w centrum), Męczeństwo, Ścięcie św. Prokulusa, Wskrzeszenie dziecka przy grobie świętego. Zdaniem Offnera poliptyk składający się z części centralnej i trzech kwater po każdej stronie byłby układem rzadkim, ale niewykluczonym ${ }^{96}$. W obu tych możliwych strukturach nad predellą znajdowałyby się całopostaciowe przedstawienia świętych; jak przyznał Offner, predelle nastaw ołtarzowych z obrazami półpostaciowymi były specjalnością ówczesnych sieneńczyków ${ }^{97}$.

Dziwić może, że Offner a priori założył, iż Giuseppe Richa widział komplet przedstawień tworzących niegdyś predellę ołtarza w kościele San Procolo, żywiąc jednocześnie przekonanie, że górna część nastawy ołtarzowej była niepełna. W świetle przytoczonego przez Offnera opisu Richy z 1754 roku należałoby sądzić, że omawiany obraz nie może być częścią tej predelli. Co prawda badacz przyznał, że predella mogła się składać również z ośmiu przedstawień (w takim układzie, jak zaznaczył, proporcje każdej ze scen byłyby zupełnie inne), ale równie możliwa była według niego predella o siedmiu przedstawieniach. Na poparcie swej tezy przywołał wspomniany fragment osiemnastowiecznego opisu, z którego jasno wynika, że Richa widział ilustracje sześciu wydarzeń z życia św. Prokulusa, prawdopodobnie rozmieszczone w siedmiu kwaterach. Jednak porównanie przywołanego przez Offnera cytatu z tekstem Richy wykazało, że badacz przytoczył jedynie część jego opisu (nie zaznaczając tego), podczas gdy dalszy fragment ma duże znaczenie dla uznania przynależności omawianego obrazu do predelli nastawy ołtarzowej z kościoła San Procolo. Richard Offner postawił bowiem kropkę po wymienieniu przez osiemnastowiecznego autora widzianych przez niego scen z życia

96 Offner przywołał dwa przykłady siedmioczęściowych poliptyków: ołtarz S. Pancrazio z Florencji autorstwa Bernarda Daddiego z Galleria degli Uffizi oraz niemal całkowicie zniszczony podczas II wojny światowej ołtarz wykonany przez Tommasa del Mazzę i Pietra Nellę z kolegiaty w miejscowości Impruneta, Offner, Elder Contemporaries, s. 124.

97 Offner, Elder Contemporaries, 137-138. 
św. Prokulusa98 tymczasem w dalszej części zdania Giuseppe Richa wyraził obawę o kompletność cyklu stwierdzając, że powinny się w nim znaleźć także inne epizody z życia świętego, w tym - „scena z Głową Kościoła”99. Nie należy zakładać, że Offner intencjonalnie skrócił opis sporządzony przez jezuitę, ale uwzględnienie całości nowożytnego sprawozdania wzbudza wątpliwość co do trafności jego rekonstrukcji ołtarza. Zastanawia także, że Offner, znając legendę o św. Prokulusie, nie dziwił się, że w cyklu z San Procolo pominięte zostało kulminacyjne wydarzenie w życiu świętego ${ }^{100}$.

Dodatkowo do Offnerowskiej rekonstrukcji retabulum z kościoła San Procolo ${ }^{101}$ (il. 11) wkradł się błąd (wynikający być może ze „skrótu myślowego" autora). Na rysunku widnieją części predelli o szerokości równej półpostaciowym przedstawieniom świętych, podczas gdy w rzeczywistości każda z części predelli ma około $32 \mathrm{~cm}$ szerokości, a szerokość wizerunków świętych wynosi około $50 \mathrm{~cm}$. Pozostając przy założeniu badacza, że ołtarz składał się z siedmiu części - sześciu o szerokości $50 \mathrm{~cm}$ i partii centralnej o połowę szerszej od pozostałych ${ }^{102}$, łatwo obliczyć, że całe retabulum musiałoby mieć około 3,75 m szerokości (bez dodania jakichkolwiek odstępów pomiędzy przedstawieniami). Taka wielkość nastawy pozwalałaby sądzić, że pierwotnie scen predelli mogło być około dziesięciu (przyjmując przynajmniej pięciocentymetrowe odstępy pomiędzy nimi) lub nawet jedenaście (bez odstępów). Jeśliby zaś Offner się mylił i retabulum pierwotnie składało się z części centralnej i czterech kwater, nadal pod nimi zmieściłoby się osiem scen predelli. Ta druga hipoteza jest jednak mniej prawdopodobna - w ówczesnych retabulach

98 „In una Galleria vi sono le storiette dipinte dal Lorenzetti contenenti alcuni fatti di S. Procolo, come della mano ad un fanciullo risanata, dei viandanti col latte di una Cerva dal Santo accorsi, del Martirio di S. Procolo, che si vede scorticato nelle reni, e poi decollato, di un morto bambino risorto al rocco del cadavere del Santo, e finalmente dove alla Messa si comunica", Richa, Notizie, 243.

99 „[...] ma notato, ed accusato di un apparente mancamento, con un miracolo è difeso, rivelando Iddio al Pontefice, che quelle irriverenze erano deliquj di anima innamorata del Sacramento", Richa, Notizie, 243. Opis Richy jest dziś bardzo cennym źródłem. Odnotował on prawdopodobny brak niektórych scen z życia św. Prokulusa, co oznacza, że retabulów obrazujących legendę tego świętego było w XVIII w. więcej, choć do dziś nie zachowało się w całości żadne z nich.

100 Offner wyjaśniał, że ustalił kolejność scen na podstawie tekstu w Acta sanctorum, wydaje się zatem oczywiste, iż musiał zapoznać się z żywotem św. Prokulusa. Offner, Elder Contemporaries, 132.

101 Offner, Elder Contemporaries, il. XXIX (Ad. pl. IV).

${ }^{102}$ Takie wnioski można wysnuć na podstawie rysunku zamieszczonego przez Offnera, zob. Offner, Elder Contemporaries, il. XXIX (Ad. pl. IV). 
zwykle zachowywano rytm przedstawień, umieszczając sceny z predelli osiowo pod przedstawieniami głównymi (np. poliptyk w kościele San Pancrazio autorstwa Bernarda Daddiego ${ }^{103}$ ).

Wydaje się pewne, że omawiane malowidło pierwotnie było częścią nastawy ołtarzowej, jednak - jak już powiedziano - konkretne jego umiejscowienie jest zadaniem trudnym; zachowane źródła do przedstawień z kościoła San Procolo nie są jednoznaczne. Pierwotnej lokalizacji obrazu nie można ustalić na podstawie jego ikonografii, sceny hagiograficzne były bowiem umieszczane zarówno w predellach, jak i w kwaterach, na rewersach bądź wokół głównego przedstawienia w kwaterze centralnej. Pomocne w skonkretyzowaniu funkcji Powitania św. Prokulusa przez papieża jest określenie prawdopodobnej liczby przedstawień wchodzących w skład retabulum, do którego zapewne należało także omawiane dzieło. Niewątpliwie scen z legendy o św. Prokulusie w ołtarzu we florenckim San Procolo było więcej niż siedem rozpoznanych przez Giuseppe Richę. Nawet przy założeniu, że Pacino di Bonaguida komponując predellę dokonał pewnego wyboru wątków (na przykład ze względu na ograniczone pole obrazowe), w świetle opisu sporządzonego przez Richę, ale także po prześledzeniu legendy o św. Prokulusie wydaje się nielogiczne, by zrezygnował akurat z jednego z najważniejszych wydarzeń w żywocie świętego (powitanie przez papieża). Tym bardziej nielogiczne, że jednocześnie przedstawił na dwóch kwaterach jeden cud (zatrzymanie łani i napojenie świętego i jego towarzyszy jej mlekiem), który był jedynie epizodem towarzyszącym spotkaniu duchownych i dla jego rozpoznania przez odbiorcę wystarczyłoby jedno z tych ujęć. Należy dodać, że legenda dotycząca tego świętego jest bardzo rozbudowana i w zachowanym cyklu dopatrywać się można wielu brakujących scen.

Przynależność zespołu kwater z obrazami z życia św. Prokulusa do predelli - choć wysoce prawdopodobna - nie jest ostatecznie przesądzona. Co prawda Giuseppe Richa użył słowa „predella” ${ }^{104}$, jednakże - jak pisał Offner - była ona już wówczas oddzielona od pozostałej części retabulum, co badacz wywnioskował na podstawie przypisania przez jezuitę autorstwa tej nastawy dwóm różnym artystom. Gdyby pójść o krok dalej i założyć, że już wtedy, w 1754 roku, owa „predella” była także rozczłonkowana - co sugeruje

${ }^{103}$ Przechowywany dziś w Galleria degli Uffizi we Florencji.

104, „....] e nella predella eranvi alcune storiette, della vita di S. Procolo, che si credono opera di Ambrogio Lorenzetti”, Richa, Notizie, 239. 
brak chronologii scen wymienionych przez Richę ${ }^{105}$ - możliwe byłyby również inne lokalizacje tego zespołu kwater w nastawie ${ }^{106}$. Teza, że omawiany obraz - i pozostałe kwatery z obrazami z życia Prokulusa - był częścią predelli jest oczywiście najbardziej wiarygodna, przy czym należałoby przyjąć, że artysta znacznie zredukował legendę świętego biskupa, wybierając z niej tylko najważniejsze sceny ${ }^{107}$. Niezależnie jednak od zakresu ograniczeń, wydaje się oczywiste, że Powitanie św. Prokulusa przez papieża musiało należeć do

${ }^{105}$ Można podejrzewać, że gdyby predella była zachowana w całości, jezuita wymieniłby sceny znajdujące się na niej po kolei, chronologicznie, od lewej strony, tak jak nakazuje naturalny odruch każdego obserwatora, tymczasem porządek wymienionych scen nie odpowiada kolejności zdarzeń w legendzie o św. Prokulusie.

${ }^{106}$ Ich kształty i rozmiary wskazują, że mogły należeć np. do kwater poliptyku ilustrujących sceny z żywota św. Prokulusa. Pacino di Bonaguida wykonał więcej prac o takim schemacie - zaliczyć do nich można Tabernaculum dei Chiarito, na którego lewym skrzydle jest 8 scen z życia Chrystusa, oraz tabernakulum z kolekcji w Tucson z 16 przedstawieniami chrystologicznymi. Przykładem florenckiej nastawy ołtarzowej z początku XIV w. o skrzydłach ze scenami narracyjnymi jest ołtarz św. Cecylii wykonany ok. 1304 r. przez Mistrza Ołtarza św. Cecylii (przechowywany w Galleria degli Uffizi we Florencji), z którego dorobku Pacino czerpał inspiracje. Ciekawym przykładem, chociaż z innego regionu Włoch, jest rekonstrukcja nastawy ołtarzowej z katedry sieneńskiej (wykonana przez Holgera Manzkego), zob. Barbara John, Holger Manzke, i Jutta Penndorf, Claritas. Das Hauptaltarbild im Dom zu Siena nach 1260. Die Rekonstruktion (Altenburg: Lindenau-Museum, 2001), 36. Cykl hagiograficzny św. Prokulusa mógł być również częścią rewersu nastawy ołtarzowej. Większość nastaw ołtarzowych ma lub miała dekorowane rewersy, odwrocia skrzydeł dyptyków i tryptyków również ozdabiano dekoracją ornamentalną lub przedstawieniami figuralnymi - np. florencki poliptyk z kościoła Santa Reparata autorstwa Giotta z ok. 1310 r., zob. Victor M. Schmidt, „Hypothesen zu Funktion und Publikum von Cenninis Libro dell'Arte,” w Fantasie und Handwerk: Cennino Cennini und die Tradition der toskanischen Malerei von Giotto bis Lorenzo Monaco, red. Wolf-Dietrich Löhr i Stefan Weppelmann (Berlin: Hirmer Verlag Gmbh, 2008), 90 - przy czym należy zaznaczyć, że sceny narracyjne na rewersach są rzadkością, jedynym przykładem jest sieneńska Maestà Duccia di Buoninsegna. Można rozważyć także teorię, że omawiane sceny znajdowały się na kwaterach nastawy ołtarzowej otaczających główne przedstawienie świętego, np. jak w XIII-wiecznym ołtarzu św. Franciszka autorstwa nieznanego florenckiego malarza z kaplicy Bardich w bazylice Santa Croce we Florencji albo w XIII-wiecznej nastawie z Pizy przedstawiającej Madonnę z Dzieciątkiem oraz sceny z życia Marii autorstwa Mistrza S. Martina (w zbiorach Museo Nazionale di San Matteo w Pizie). Przyjmując tę możliwość należałoby założyć, że pierwotnie istniała nieznana dziś część centralna, przedstawiająca całopostaciową figurę św. Prokulusa.

${ }^{107}$ Należy pamiętać, że nie wiemy dziś, jaką wersję legendy o św. Prokulusie znano w XIV w., być może pierwsza część hagiografii, opowiadająca o przyjaźni świętego ze św. Walentym biskupem Terni, powstała w późniejszym czasie w wyniku pomieszania historii Prokulusa z żywotami innych kanonizowanych postaci lub została odrzucona $\mathrm{z}$ oficjalnej wersji hagiografii Prokulusa ze względu na niezgodność chronologiczną, św. Prokulus bowiem miał umrzeć w VI w., św. Walenty biskup Terni zaś poniósł śmierć męczeńską w 269 r., zob. Wincenty Zaleski, Święci na każdy dzień (Warszawa: Wydawnictwo Salezjańskie, 1996), 94. 
zespołu malowideł, ponieważ bez tego przedstawienia przerwana zostałaby ciągłość i logika zobrazowania życia i męczeństwa świętego.

Warto dodać, że również owa predella mogła należeć do całkiem innej nastawy niż zrekonstruowana przez Richarda Offnera na podstawie nowożytnych źródeł. Jak już wspomniano, badacz pisał, że to sieneńczycy zaopatrywali w predelle nastawy ołtarzowe z półpostaciowymi przedstawieniami świętych ${ }^{108}$. Być może Rafaello Borghini nie wspomniał w 1584 roku o predelli nie z tej przyczyny, że ołtarz z przedstawieniem Madonny z Dzieciątkiem został rozczłonkowany, lecz dlatego że predella ze św. Prokulusem nigdy do niego nie należała? Porzucenie koncepcji Offnera pozwalałoby zakładać, że predella zawierała większą liczbę scen ${ }^{109}$.

Kwestia funkcji, jaką pełnić miał obraz ze świętym Prokulusem i papieżem pozostaje zatem w pewnym stopniu otwarta. Z pewnością należał on do nastawy ołtarzowej, która mieściła cykl ośmiu lub więcej obrazów ze scenami z żywota biskupa, dziś rozproszonych w różnych zbiorach. Można z dużym prawdopodobieństwem zakładać, że owo retabulum pochodziło z kościoła San Procolo znajdującego się przy via de' Giraldo we Florencji.

Malowidło, pomimo niewielkich rozmiarów i niepozornego wyglądu, okazuje się dziełem bez wątpienia wyjątkowym. Przedstawiona w niniejszym opracowaniu argumentacja wskazuje na jego związek z retabulum św. Prokulusa z kościoła San Procolo we Florencji i autorstwo Pacina di Bonaguidy. Obraz - jedyne domniemane dzieło tego artysty w zbiorach polskich - jawi się także jako unikat ikonograficzny na tle całego znanego dziś materiału zabytkowego. Zaproponowana identyfikacja nieznanego wcześniej obrazu stanowi istotny asumpt do dalszych badań nad twórczością włoskiego mistrza; w istotny sposób zmienia też dotychczasowe rozpoznanie retabulum z San Procolo, otwierając nowe możliwości jego interpretacji.

108 Offner, Elder Contemporaries,137-138.

109 Ta część retabulum mogłaby pomieścić większą liczbę przedstawień, gdyby Pacino zaprojektował nastawę ołtarzową podobną do wykonanej przez Bernarda Daddiego w 1344 r. dla kościoła Santa Reparata we Florencji (zob. Schmidt, „Hypothesen”, 88) - mianowicie rozbudowany poliptyk z podwójną predellą ze scenami narracyjnymi. 


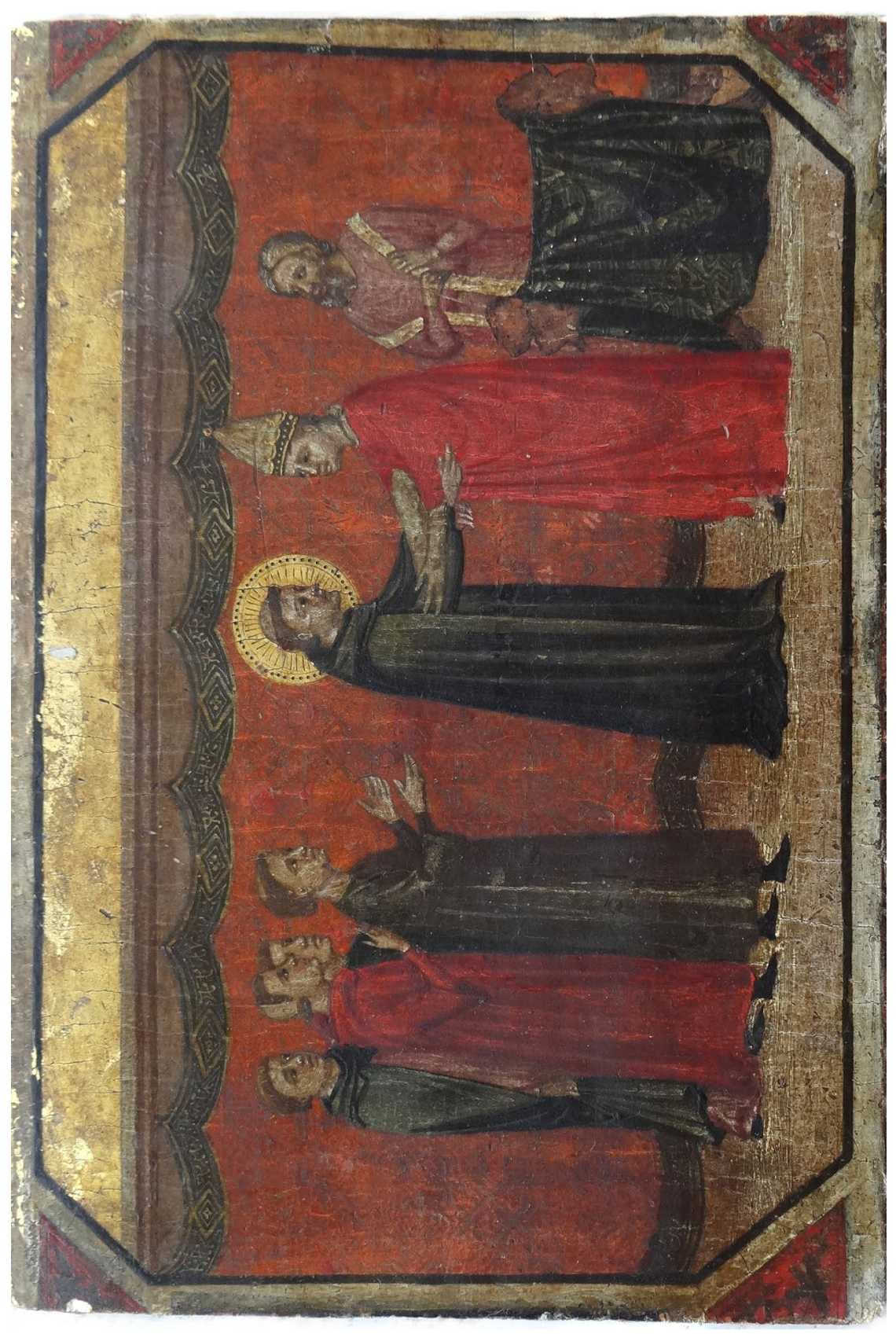

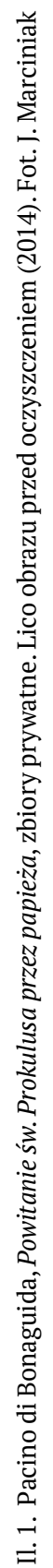



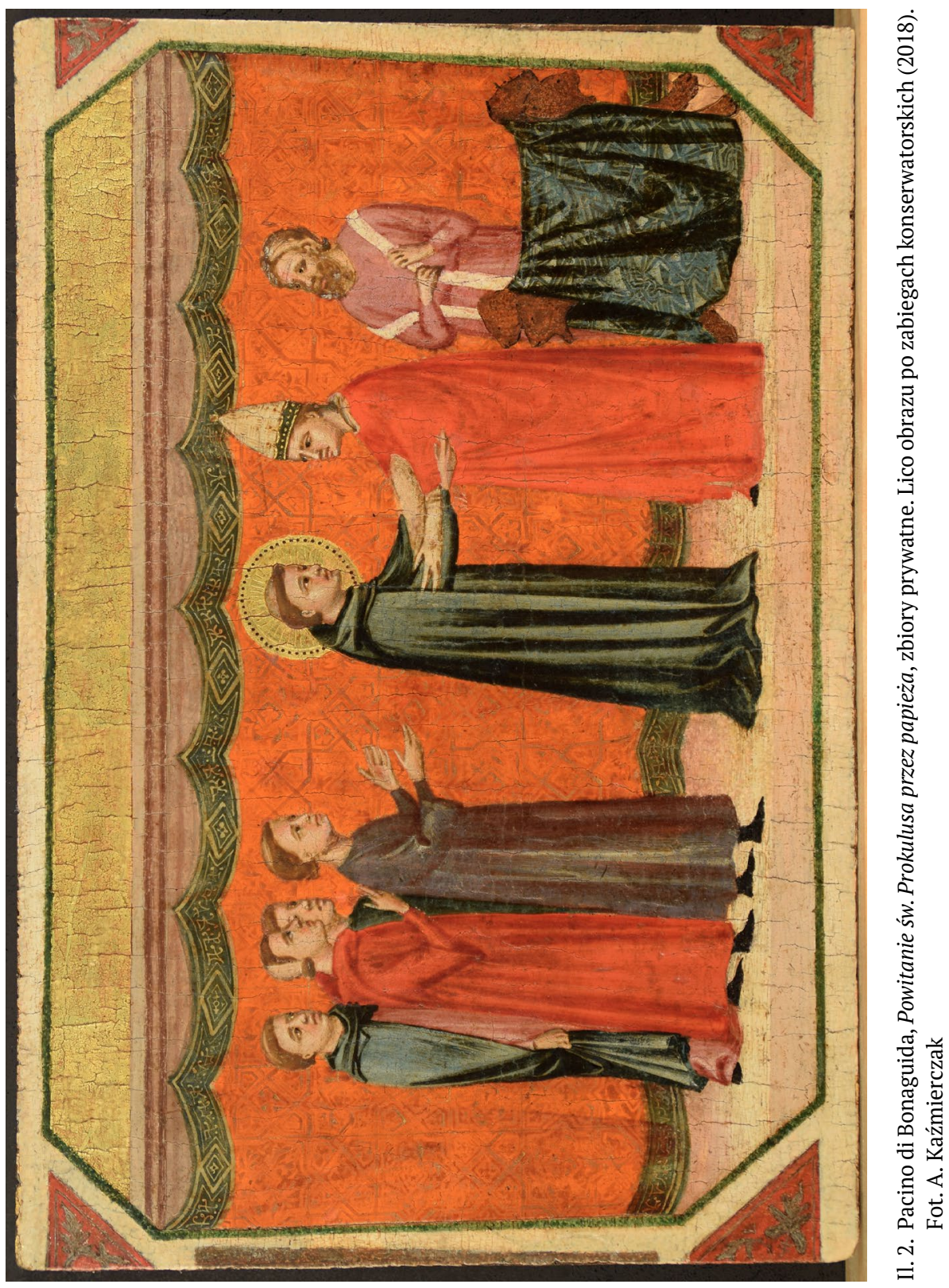


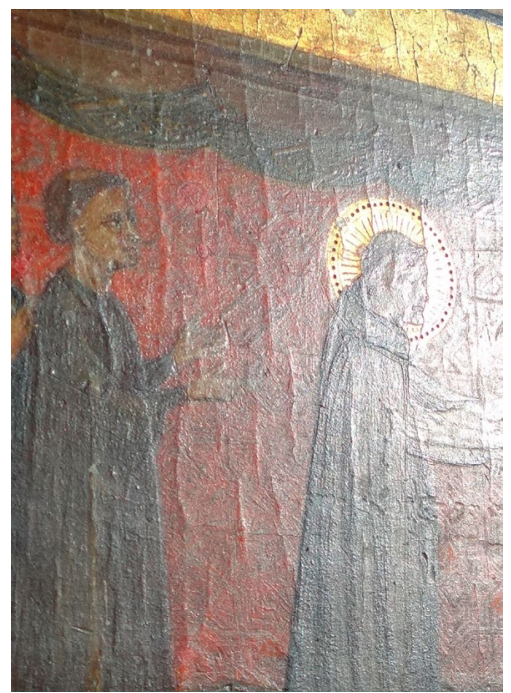

Il. 3. Pacino di Bonaguida, Powitanie św. Prokulusa przez papieża, zbiory prywatne. Detal lica obrazu przed oczyszczeniem w świetle skośnym (2015) - spękania warstwy malarskiej. Fot. J. Marciniak

a

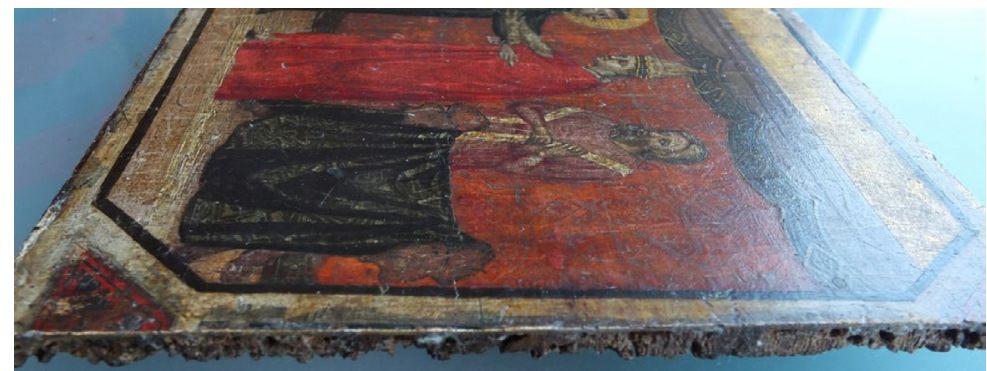

$\mathrm{b}$

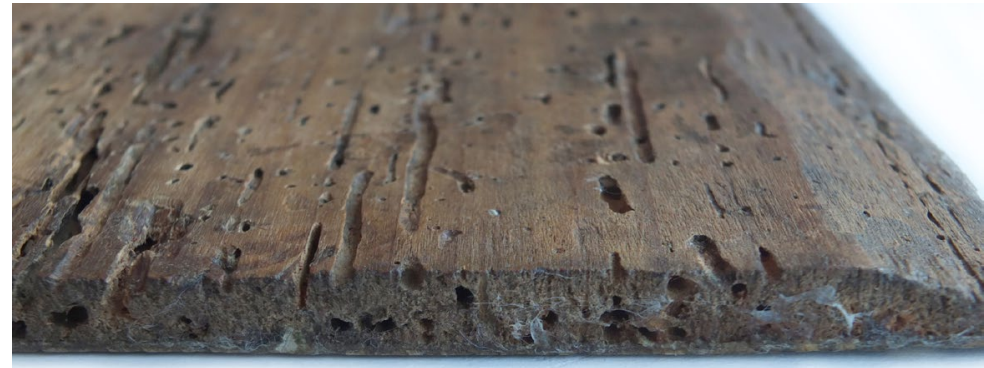

Il. 4. Pacino di Bonaguida, Powitanie św. Prokulusa przez papieża, zbiory prywatne. Fragmenty boku podobrazia: a - przed oczyszczeniem lica, b - przed zawoskowaniem odwrocia (2015). Fot. J. Marciniak 
a

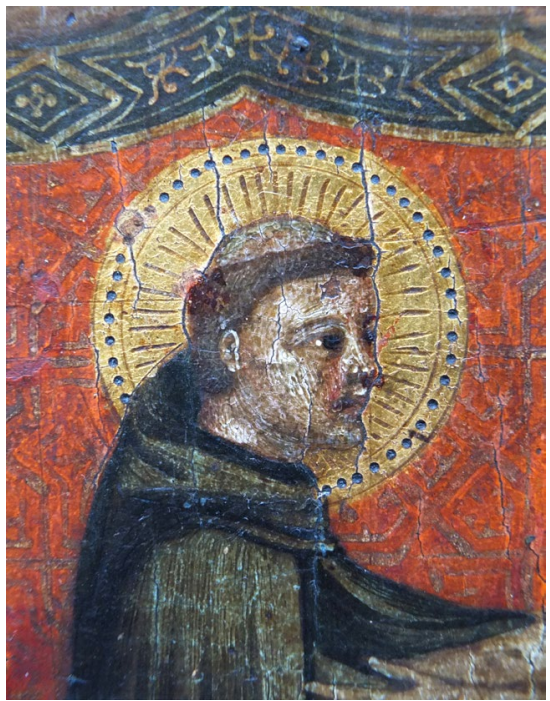

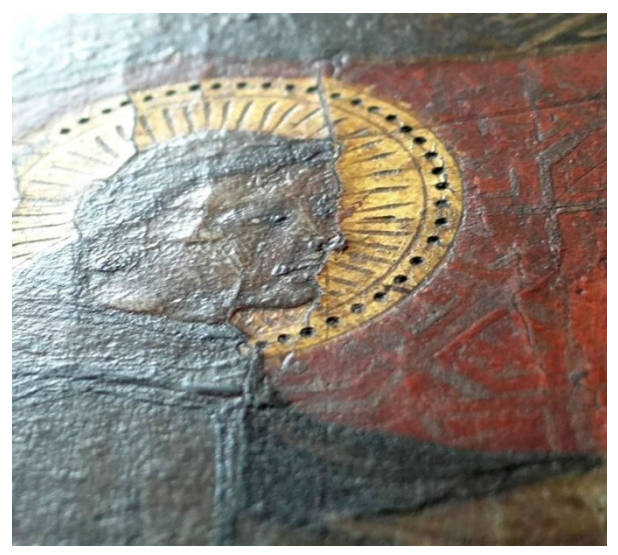

Il. 5. Pacino di Bonaguida, Powitanie św. Prokulusa przez papieża, zbiory prywatne. Detal lica obrazu przed oczyszczeniem (2015) - obrys złotego nimbu świętego: a - w świetle naturalnym, b - w świetle skośnym. Fot. J. Marciniak

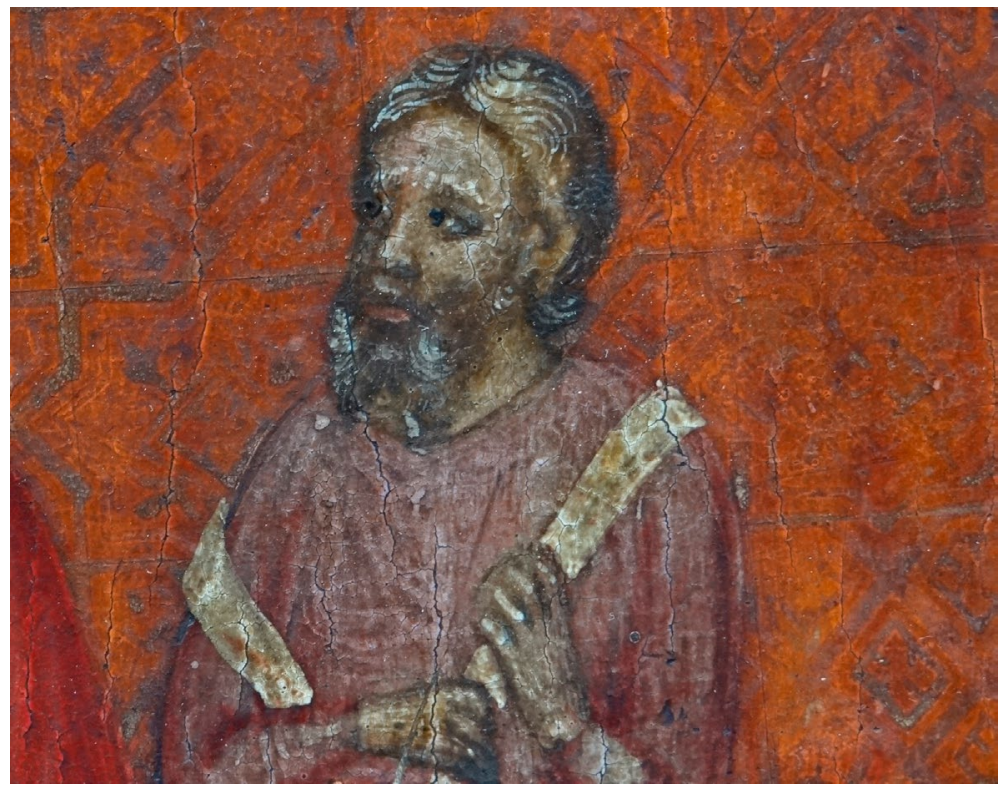

Il. 6. Pacino di Bonaguida, Powitanie św. Prokulusa przez papieża, zbiory prywatne. Fragment lica obrazu przed oczyszczeniem (2014) - czytelne opracowanie włosów starszego duchownego. Fot. J. Marciniak 


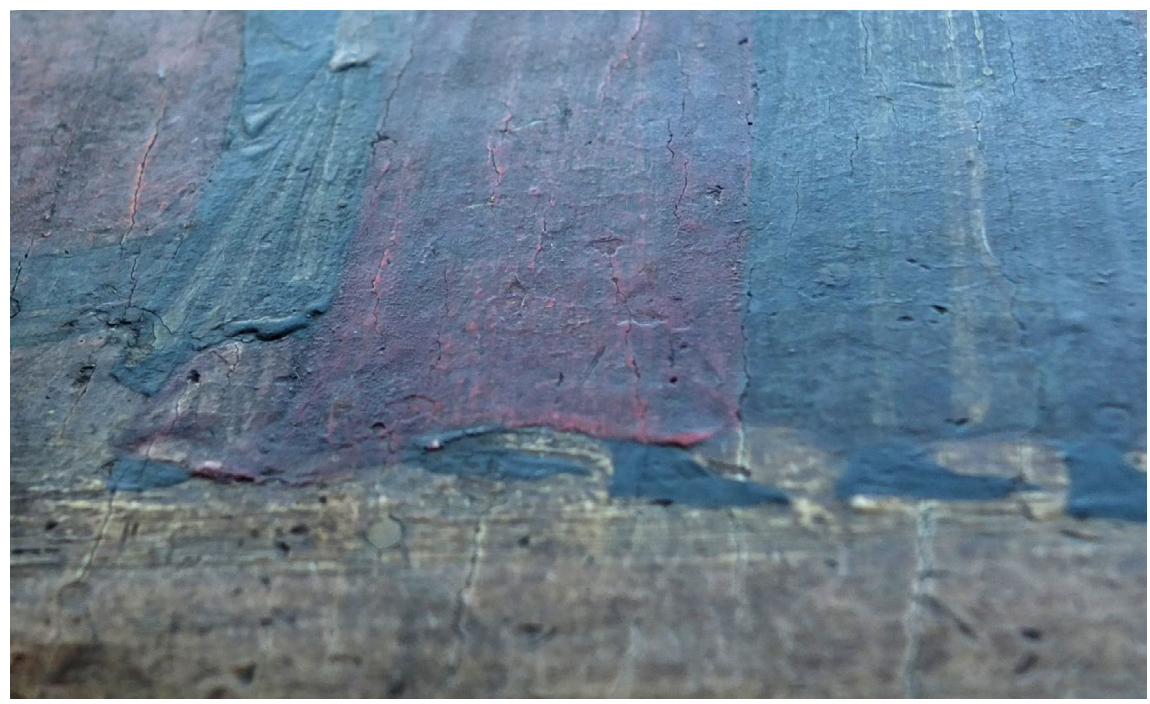

Il. 7. Pacino di Bonaguida, Powitanie św. Prokulusa przez papieża, zbiory prywatne. Detal lica obrazu przed oczyszczeniem (2015) - zacieki farby. Fot. J. Marciniak

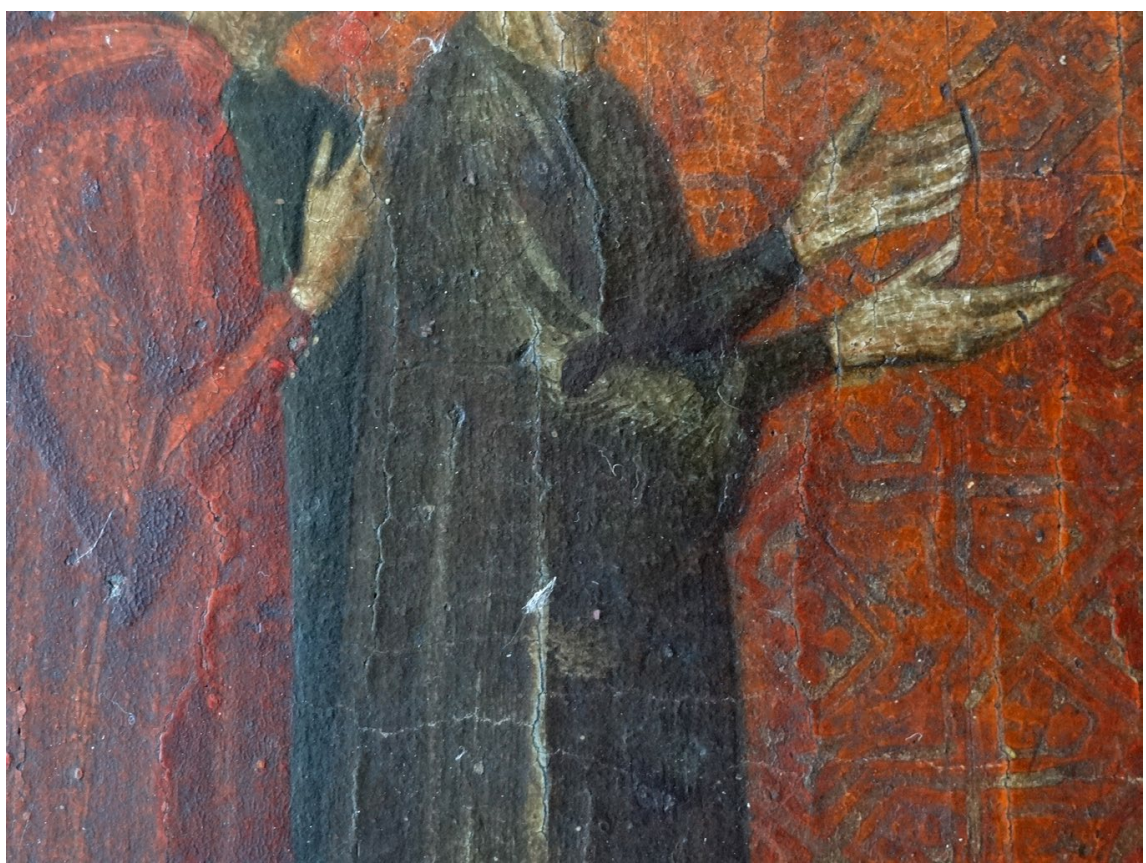

Il. 8. Pacino di Bonaguida, Powitanie św. Prokulusa przez papieża, zbiory prywatne. Detal lica obrazu przed oczyszczeniem (2015) - dłonie towarzyszy świętego. Fot. J. Marciniak 


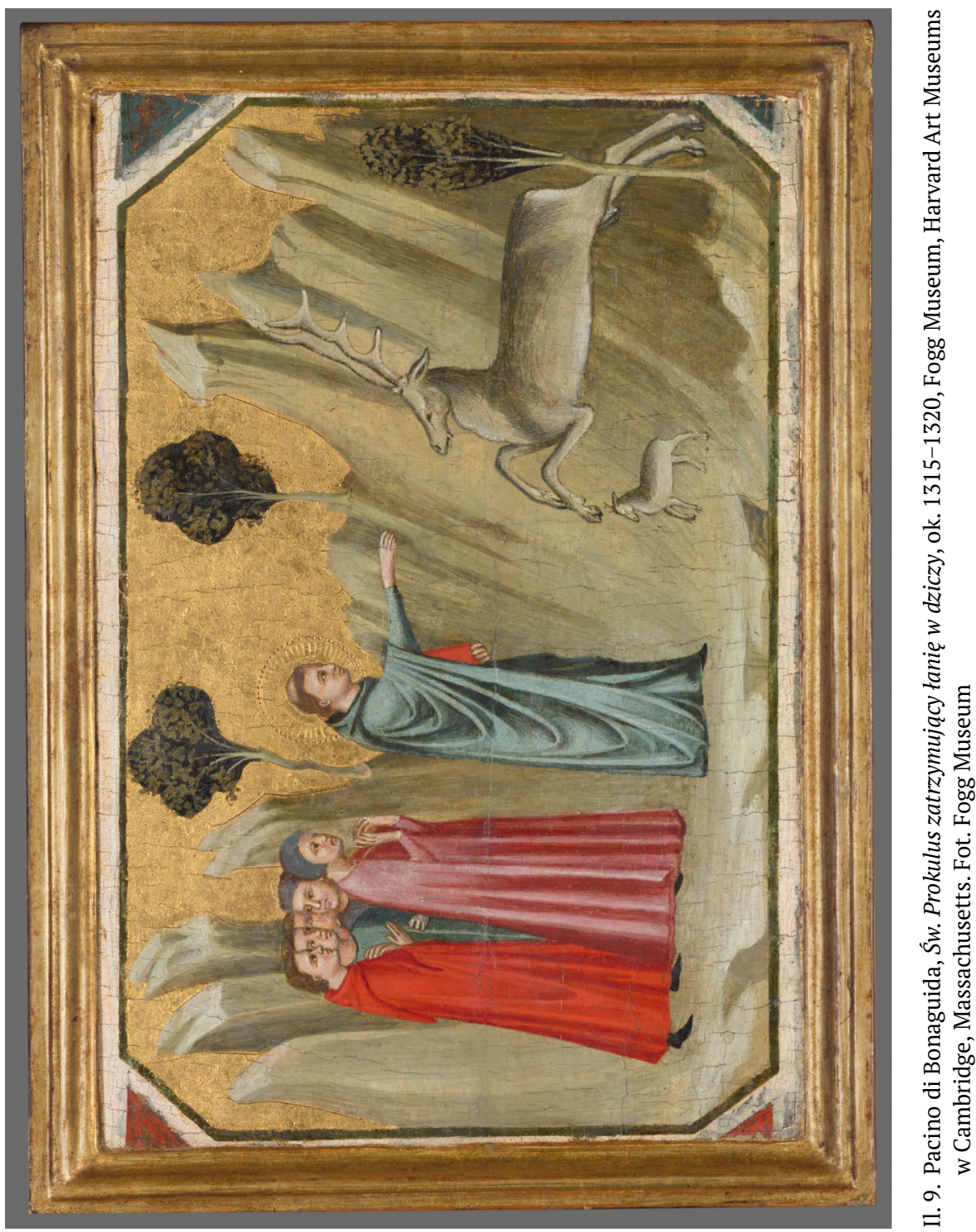



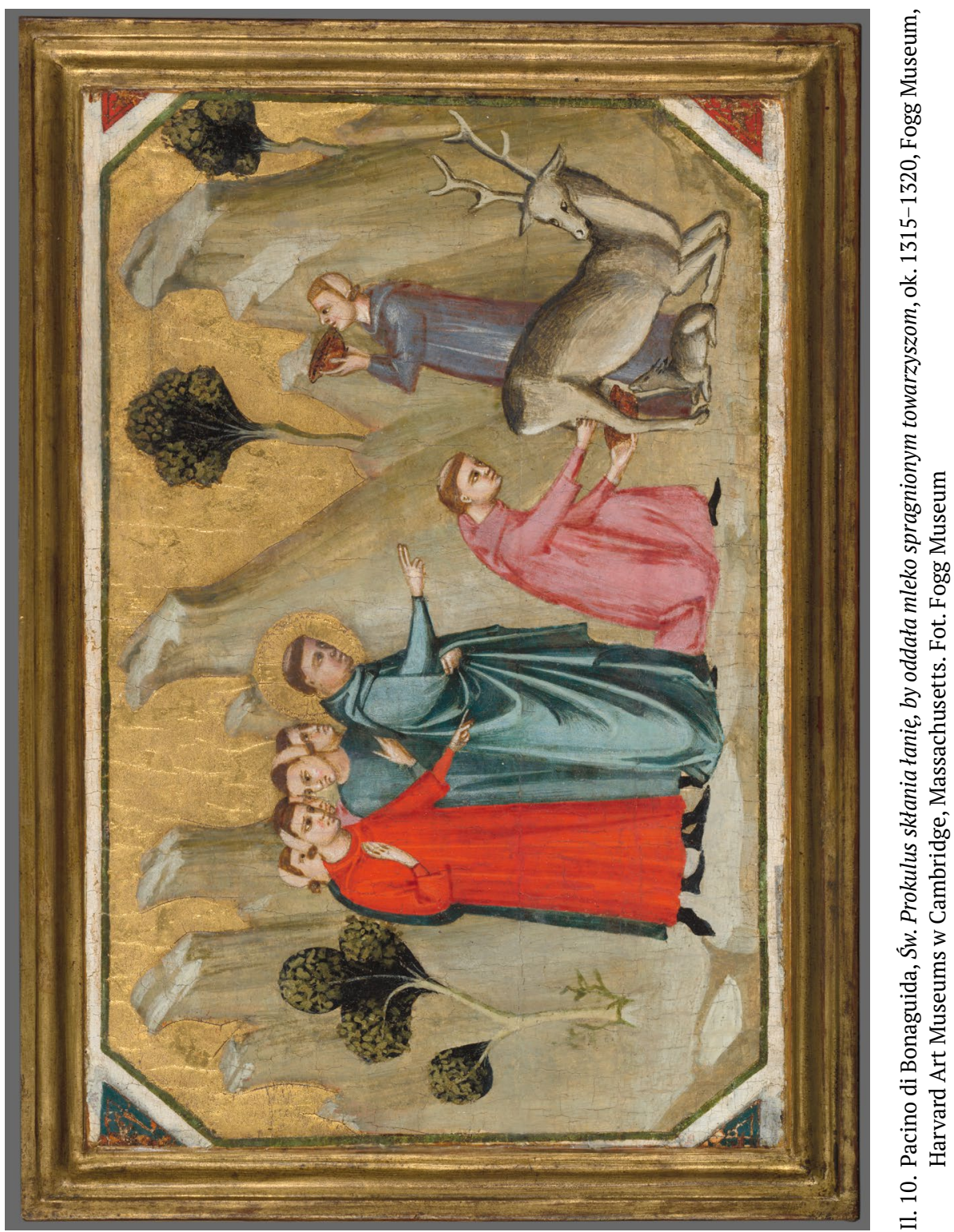


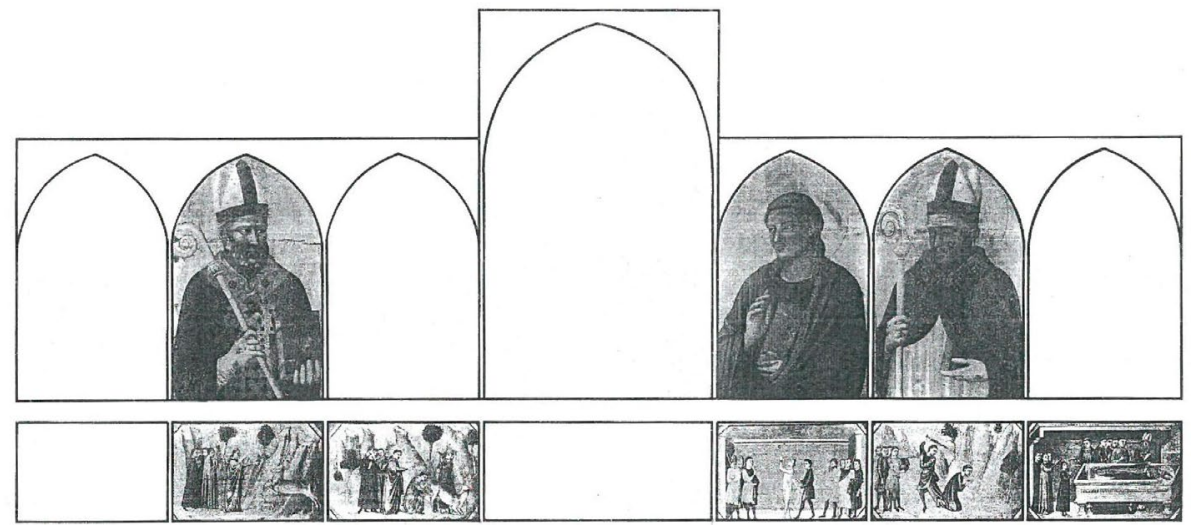

Il. 11. Rekonstrukcja ołtarza z kościoła San Procolo we Florencji według Richarda Offnera, za: Richard Offner, Elder Contemporaries of Bernardo Daddi (A Critical and Historical Corpus of Florentine Painting, sec. 3, vol. 2, red. Richard Offner i Klara Steinweg, New York: Institute of Fine Arts, New York University, 1956), continued under the direction of Miklós Boskovits and Mina Gregori, A new edition with additional notes and bibliography by Miklós Boskovits (Florence: Instituto di Storia Dell'Arte of The University of Florence, 1987), 125, il. XXIX 


\section{Bibliografia}

Blewett, Morwenna. „Treatment Report. Accession number: 1943.110.” Dokumentacja konserwatorska, Cambridge 2006, Straus Center for Conservation Harvard University Art Museums.

Blewett, Morwenna. „Treatment Report. Accession number: 1943.111.” Dokumentacja konserwatorska, Cambridge 2006, Straus Center for Conservation Harvard University Art Museums.

Borghini, Rafaello. Il riposo, in cui della pittura e della scultura si favella, e' più illustri pittori, e scultori, e delle più famose opere loro si fa mentione, e le cose proncipali appertenenti a dette arti s'insegnano. Fiorenza: Marescotti, 1584.

Boskovits, Miklós. The Fourteenth Century: The Painters of the Miniaturists Tendency (A Critical and Historical Corpus of Florentine Painting. Sec. 3, vol. 9). Florence: Giunti Barbèra, 1984.

Boskovits, Miklós, i Angelo Tartuferi. Dipinti. Volume primo: Dal Duecento a Giovanni da Milano. Firenze: Giunti, 2003.

Cennini, Cennino. Il libro dell'arte: Trattato della pittura di Cennino Cennini, di nuovo publicato con molte correzioni e coll'aggiunta di piu capitoli tratti dai codici Fiorentini pre cura di Caetano e Carlo Milanesi. Firenze: Le Monnier, 1859.

Cennini, Cennino. Rzecz o malarstwie. Przekład typografów z inicjatywy Towarzystwa Zachęty Sztuk Pięknych w Warszawie. Florencja: Florencka Oficyna Tyszkiewiczów, 1933.

Colnaghi, Dominic Ellis. A Dictionary of Florentine Painters: from the $13^{\text {th }}$ to the $17^{\text {th }}$ Centuries, red. P. G. Konody i Selwyn Brinton. London: John Lane the Bodley Head, 1928.

Florence at the Dawn of the Renaissance: Painting and Illumination, 1300-1350. Red. Christine Sciacca. Los Angeles: J. Paul Getty Museum, 2012.

Frey, Karl. Die Loggia dei Lanzi zu Florenz: eine quellenkritische Untersuchung. Berlin: Wilhelm Hertz, 1885.

Guernelli, Daniele. „A New Manuscript for Pacino di Buonaguida.” Manuscripta: A Journal for Manuscript Research 55, no. 2 (2011): 192-204.

Gutkowska-Rychlewska, Maria. Historia ubiorów. Wrocław-Warszawa-Kraków: Zakład Narodowy im. Ossolińskich, 1968.

Henchenio, Godefrido, Daniele Papebrochio, Francesco Baertio, i Conrado Janningo. Acta sanctorum quotquot toto orbe coluntur, vel a catholicis scriptoribus celebrantur quae ex latinis et graecis, aliarumque gentium antiquis monumentis. Junii. T. 1. Parisiis et Romæ: APUD Victorem Palmé, 1867.

Iwaszkiewicz, Piotr, Wiesław Łoś, i Marek Stępień. Władcy $i$ wodzowie starożytności. Słownik. Warszawa: WSiP, 1998.

John, Barbara, Holger Manzke, i Jutta Penndorf. Claritas. Das Hauptaltarbild im Dom zu Siena nach 1260. Die Rekonstruktion. Altenburg: Lindenau-Museum, 2001. 
Kaftal, George. Iconography of the Saints in Tuscan Painting. Florence: Sansoni, 1952.

Kanter, Laurence B., i Barbara Drake Boehm. Painting and Illumination in Early Renaissance in Florence, 1300-1450. New York: The Metropolitan Museum of Art, 1994.

Keene, Bryan C. Wprowadzenie do Florence at the Dawn of the Renaissance: Painting and Illumination, 1300-1350, red. Christine Sciacca, 1-7. Los Angeles: J. Paul Getty Museum, 2012.

Labriola, Ada. „Pacino di Buonaguida.” W Dizionario biografico dei miniatori italiani. Secoli IX-XVI, red. Milvia Bollati, 841-843. Milano: Sylvestre Bonnard, 2004.

Levi D’Ancona, Mirella. Miniatura e miniatori a Firenze dal XIV al XVI secolo: documenti per la storia della miniature. Firenze: Leo S. Olschki, 1962.

Marciniak, Jagoda. „Nieznane dzieło doby Trecenta z kolekcji prywatnej. Analiza zabytkoznawcza.” Praca magisterska, Uniwersytet Mikołaja Kopernika w Toruniu, 2016.

Marciniak, Jagoda. „Pacino di Bonaguida (czynny w latach ok. 1303-1340) z warsztatem: Powitanie św. Prokulusa z papieżem.” W Włochy w Gdańsku, red. Marcin Kaleciński. T. 2 Katalog zabytków, 46-48. Gdańsk: Muzeum Narodowe, 2019.

Marconi, Bohdan. „Znaczenie traktatu Cenniniego w historii technik malarskich.” W Cennino Cennini, Rzecz o malarstwie. Tłumaczenie Samuel Tyszkiewicz, s. XV-XXI. Wrocław: Ossolineum, 1955.

McBrien, Richard P. Leksykon papieży: pontyfikaty od Piotra Apostoła do Jana Pawła II. Warszawa: Świat Książki, 2003.

Milanesi, Gaetano. Nuovi documenti per la storia dell'arte Toscana. Firenze: G. Dotti, 1901.

Offner, Richard. „Pacino di Bonaguida, a Contemporary of Giotto.“ Art in America 11 (1922): 3-27.

Offner, Richard. Studies in Florentine Painting. The Fourteenth Century. New York: Federic Fairchild Scherman, 1927.

Offner, Richard. The Fourteenth Century (A Critical and Historical Corpus of Florentine Painting. Vol. 3). New York: College of Fine Arts, New York University, 1930.

Offner, Richard. Elder Contemporaries of Bernardo Daddi (A Critical and Historical Corpus of Florentine Painting, sec. 3, vol. 2), red. Richard Offner i Klara Steinweg, New York: Institute of Fine Arts, New York University, 1956, continued under the direction of Miklós Boskovits and Mina Gregori, A new edition with additional notes and bibliography by Miklós Boskovits. Florence: Instituto di Storia Dell'Arte of The University of Florence, 1987.

Olender, Jacek [pod kierunkiem dr Joanny Arszyńskiej]. „Powitanie świętego Bernarda przez Innocentego III, I poł. XIV wieku. Obraz temperowy na desce. Dokumentacja prac konserwatorskich i restauratorskich.” Dokumentacja konserwatorska, Toruń 2011, Zakład Konserwacji Malarstwa i Rzeźby Polichromowanej UMK, NR ZKMIRZP 1506.

Olender, Jacek, Elena-Teodore Nacula, i Adam Kazimierczak [pod kierunkiem dr Joanny Arszyńskiej]. „Dokumentacja prac konserwatorskich i restauratorskich nr 1506.” 
Dokumentacja konserwatorska, Toruń 2018, Katedra Konserwacji-Restauracji Malarstwa i Rzeźby Polichromowanej UMK, NR KKRMIRZP 1506.

Palladino, Pia. Treasures of a Lost Art: Italian Manuscript Painting of the Middle Ages and Renaissance. New York: Yale University Press, 2003.

Pasut, Francesca. „La Bibbia Trivulziana di Pacino di Bonaguida. La decorazione miniata del codice Trivulziano 2139: una impresa di équipe." Libri \& Documenti. Archivio Storico Civico e Biblioteca Trivulziana 39 (2013): 27-50.

Pasut, Francesca. „Pacino di Bonaguida e le miniature della Divina Commedia: un percorso tra codici poco noti." W Da Giotto a Botticelli: pittura fiorentina tra gotico e Rinascimento: atti del convegno internazionale, Firenze, Università degli studi e Museo di San Marco, 20-21 maggio 2005, red. Francesca Pasut i Johannes Tripps, 41-62. Firenze: Giunti, 2008.

Payanotova, Stella. „New Miniatures by Pacino di Bonaguida in Cambridge.” The Burlington Magazine 151 (2009): 144-147.

Pontone, Marzia. „La Bibbia Trivulziana di Pacino di Bonaguida. Note sul riesame dell'allestimento materiale del codice Trivulziano 2139.” Libri \& Documenti. Archivio Storico Civico e Biblioteca Trivulziana 39 (2013): 7-25.

Prokopp, Mária. Die Malerei des Trecento. Budapest: Corvina, 1986.

Richa, Giuseppe. Notizie istoriche delle chiese fiorentine, divise ne' suoi quartieri. Vol. 1. Firenze: Pietro Gaetano Viviani, 1754.

Sauer, Rita. „'...so soll auch euer ganzes Leben heilig werden’. Das Vitenretabel.“ W Kult Bild: das Altar und Andachtsbild von Duccio bis Perugino, red. Jochen Sander, 130-176. Frankfurt am Main: Städelsches Kunstinstitut, 2006.

Sciacca, Christine. „Pacino di Bonaguida and His Workshop.” W Florence at the Dawn of the Renaissance: Painting and Illumination, 1300-1350, red. Christine Sciacca, 285-303. Los Angeles: J. Paul Getty Museum, 2012.

Schmidt Patterson, Catherine, Alan Phenix, i Karen Trentelman. „Scientific Investigation of Painting Practices and Materials in the Work of Pacino di Bonaguida.” W Florence at the Dawn of the Renaissance: Painting and Illumination, 1300-1350, red. Christine Sciacca, 361-371. Los Angeles: J. Paul Getty Museum, 2012.

Schmidt, Victor M. „Hypothesen zu Funktion und Publikum von Cenninis Libro dell'Arte”. W Fantasie und Handwerk: Cennino Cennini und die Tradition der toskanischen Malerei von Giotto bis Lorenzo Monaco, red. Wolf-Dietrich Löhr i Stefan Weppelmann, 147-151. Berlin: Hirmer Verlag, 2008.

Skubiszewska, Maria. Malarstwo Italii w latach 1250-1400 (Malarstwo Europejskie w Średniowieczu, t. 4). Warszawa: Auriga, 1980.

Szafran, Yvonne, i Nancy Turner. „Techniques of Pacino di Bonaguida, Iluminator and Panel Painter." W Florence at the Dawn of the Renaissance: Painting and Illumination, 1300-1350, red. Christine Sciacca, 335-355. Los Angeles: J. Paul Getty Museum, 2012. 
Thieme, Ulrich, i Felix Becker. Allgemeines Lexikon der bildenden Künstler von der Antike bis zur Gegenwart. T. 26. Leipzig: E. A. Seemann, 1992.

Tylewicz, Arleta. Sztuka pozłotnictwa i inne techniki zdobienia. Poznań: eMPi2, 2007. Zaleski, Wincenty. Święci na każdy dzień. Warszawa: Wydawnictwo Salezjańskie, 1996. Zanotti, Ercole Maria. Storia dei santi Procolo soldato cavalier bolognese, e protettore della sua patria, e Procolo Siro vescovo di Terni ambedue martiri composta e di alcune annotazioni accresciuta da Ercole Maria Zanotti bolognese. Bologna: a S. Tommaso d'acquino, 1742. 